\title{
Depositional architecture and palaeogeographic significance of Middle Pleistocene glaciolacustrine ice marginal deposits in northwestern Germany: a synoptic overview
}

\author{
Jutta Winsemann, Christian Brandes, Ulrich Polom, Christian Weber
}

Abstract:

\begin{abstract}
Ice-marginal deposits are important palaeogeographic archives, recording the glacial history of sedimentary basins. This paper focuses on the sedimentary characteristics, depositional history and palaeogeographic significance of ice-marginal deposits in the Weserbergland and Leinebergland, which were deposited into deep proglacial lakes at the terminus of the Saalian Drenthe ice sheet. The depositional architecture and deformation patterns of ice-marginal deposits will be discussed with respect to glacier termini dynamics, lake-level fluctuations and basement tectonics. During the last 10 years, a total of 27 sand and gravel pits and more than 4000 borehole logs were evaluated in order to document the regional pattern and character of Middle Pleistocene ice-marginal deposits. The field study was supported with a shear-wave seismic survey. Based on this data set, and analysis of digital elevation models with geographic information systems (GIS), we attempt to improve earlier palaeogeographic reconstructions of glacial lakes in the Weserbergland and Leinebergland and reconcile some inconsistencies presented in the current valley-fill models. We hypothesize that the formation and catastrophic drainage of deep proglacial lakes in front of the Drenthe ice sheet considerably influenced the ice-sheet stability and may have initiated the Hondsrug ice stream and rapid deglaciation. Based on our analysis, it seems unlikely that the Elsterian ice sheet reached farther south than the Saalian Drenthe ice sheet in the study area.
\end{abstract}

[Faziesarchitektur und paläogeographische Bedeutung mittelpleistozäner glazilakustriner Eisrandsysteme in NordwestDeutschland: ein synoptischer Überblick]

Kurzfassung:

Eisrandsysteme sind bedeutende paläogeographische Archive, die die Vereisungsgeschichte in marinen und kontinentalen Becken aufzeichnen. Im Fokus dieser Arbeit stehen saalezeitliche, glazilakustrine Eisrandablagerungen des Weser-und Leineberglandes, die in etwa die maximale Ausdehnung des saalezeitlichen Drenthe-Eisschildes markieren. Die Faziesarchitektur und die internen Deformationstrukturen dieser Eisrandablagerungen werden in Hinblick auf Gletscherdynamik, hochfrequente Seespiegelschwankungen und Basement-Tektonik diskutiert. In den letzen 10 Jahren haben wir im Weser- und Leinebergland 27 Kies- und Sandgruben neu bearbeitetet und mehr als 4000 Bohrungen ausgewertet, um die saalezeitliche Sedimentation im Bereich des Eisrandes und der vorgelagerten Seebecken zu rekonstruieren. Die Geländearbeiten wurden durch Scherwellenseismik-Profile ergänzt. Basierend auf diesen Daten wurden mit Hilfe von digitalen Höhenmodellen und geographischen Informationssystemen (GIS) saalezeitliche Eisstauseen im Weser- und Leinebergland rekonstruiert.

Wir vermuten, dass die Bildung und das katastrophale Auslaufen dieser tiefen Eisstausseen die Stabilität des drenthezeitlichen Eisschildes stark beeinflusst und möglicherweise den Hondsrug Eisstrom initiiert haben. Unsere Studie zeigt darüber hinaus, dass der elsterzeitliche Eisschild vermutlich nicht weiter als der drenthezeitliche Eisschild nach Süden vorgedrungen ist, als bisher angenommen wurde.

Keywords: $\quad$ glacial Lake Weser, glacial Lake Leine, subaqueous ice-contact fans, ice-marginal deltas, normal faults, Saalian glaciation, Elsterian glaciation, Hondsrug ice stream, north west Germany

Addresses of authors: J. Winsemann, C. Brandes, C. Weber, Leibniz Universität Hannover, Institut für Geologie, Callinstrasse 30, 30167 Hannover, Germany. E-Mail: winsemann@geowi.uni-hannover.de; U. Polom, Leibniz Institut für Angewandte Geophysik (LIAG), Hannover, Germany; C. Weber, Planungsbüro Umwelt und Geodaten, An der Strangriede 4A, 30167 Hannover

\section{Introduction}

In numerous places across central Europe, ice-marginal lakes formed due to the blocking of river systems by Pleistocene ice sheets (e.g., EIssmann 1997, 2002, JUNGE 1998). The blocking of the Upper Weser and Upper Leine Valley by the Saalian Drenthe ice sheet must have led to a disruption of the northward river drainage and the initiation of glacial lake formation. However, the existence and size of these glacial lakes has been controversial for about 100 years and various palaeogeographic reconstructions have been proposed. Reconstructions based on fine-grained lake bottom sediments in the northernmost part of the Upper Weser and Leine Valley indicate small and very shallow glacial lakes (e.g., Spethmann 1908, Feldmann 2002). In contrast, Thome (1983) and Klostermann (1992) argued that glacial lake Weser stood at a level of $300 \mathrm{~m}$ a.s.l., controlled by the altitudes of potential outlet channels and inferred water depth to be up to $250 \mathrm{~m}$. More recent studies assume maximum lake levels of approximately $200 \mathrm{~m}$ a.s.l. for both glacial Lake Weser and glacial Lake Leine (Тноме 1998, WinSEMANN et al. 2007b, 2009, 2011).

This long-term debate probably reflects problems recognizing short-lived lakes in steeper terrains. Compared to large ice-dammed lakes with long-lived stable water levels, smaller short-lived lakes are much more difficult to map because their shoreline features are commonly less well developed and less abundant. Although shoreline features have been reported from other high-relief lake areas 


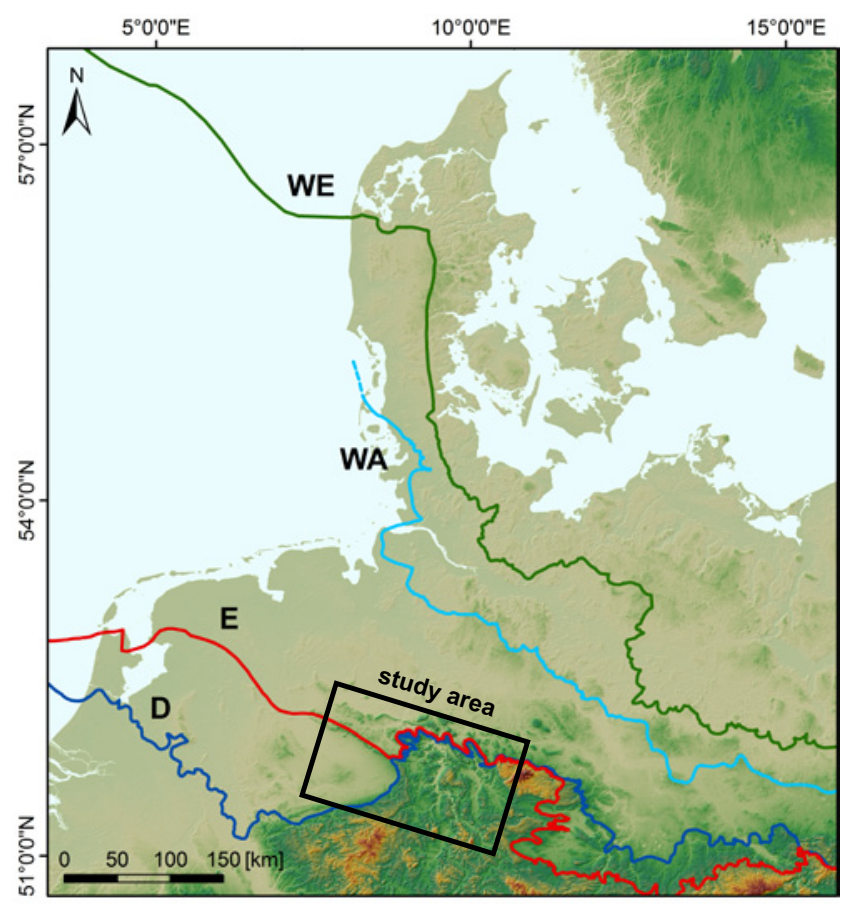

Fig. 1: Extent of the Pleistocene ice sheets in central Europe. E: Maximum extent of the Elsterian ice-margin. D: Maximum extent of the Saalian Drenthe ice-margin. WA: Maximum extent of the Saalian Warthe ice-margin. WE: Maximum extent of the Weichselian ice-margin. Modified after EHLERS et al. (2004).

Abb. 1: Ausdehnung der Pleistozänen Eisschilde in Mitteleuropa. E: Maximale Ausdehnung des elsterzeitlichen Eisschildes. D: Maximale Ausdeh-

nung des saalezeitlichen Drenthe Eisschildes. WA: Maximale Ausdehnung des saalezeitlichen Warthe Eisschildes. WE: Maximale Ausdehnung des weichselzeitlichen Eisschildes. Verändert nach EHLERS et al. (2004).

(e.g., Carling et al. 2002, Johnsen \& Brennand 2006) they are probably rare in steep short-lived glacial lakes, characterized by rapid lake-level fluctuations. After lake drainage these sparse shoreline features may be rapidly eroded by postglacial erosion (e.g., COLMAN et al. 1994, LARoQue, DuBOIS \& LEBLON 2003).

The study reported here focuses on the sedimentary characteristics, depositional history and palaeogeographic significance of glaciolacustrine ice-marginal deposits in the Upper Weser and Upper Leine Valley, which formed at the terminus of the Drenthe ice sheet. The objective is to provide a synthesis of the stratigraphic architecture of glaciolacustrine ice-marginal deposits. The depositional architecture and deformation patterns of these deposits will be discussed with respect to glacier termini dynamics, lakelevel fluctuations and basement tectonics. We employ digital elevation models and geographic information systems (GIS) to improve earlier palaeogeographic reconstructions of glacial Lake Weser and glacial Lake Leine and attempt to reconcile some inconsistencies present in the current valley-fill models.

\section{Study area and previous research}

The study area is located in the Weserbergland and Leinebergland area south of the North German Lowlands (Fig. 1 and Fig. 2). The terrain is characterized by several mountain ridges up to $400 \mathrm{~m}$ high, mainly made up by
Mesozoic sedimentary rocks and broad valleys of the River Weser and the River Leine. It is still under debate if the study area was affected by both the Elsterian and Saalian Drenthe glaciations. The reconstruction of the Elsterian ice margin is difficult because the sediments became overridden by the later Saalian ice sheet (e.g., CASPERS et al. 1995). The Elsterian ice-margin probably terminated north of the Teutoburger Wald Mountains (EHLERs et al. 2004). Most reconstructions assume that ice lobes of the Elsterian ice sheet advanced into the Upper Weser and Leine Valleys (e.g., LiedtKe 1981, JoRdAn 1989, Klostermann 1992, 1995, Thome 1998, Rohde \& Thiem 1998, Feldmann 2002). This assumption is mainly based on the occurrence of scattered erratic clasts beyond the Saalian ice-margin (e.g., WALDECK 1975, JORDAN 1994), the occurrence of reworked erratic clasts in middle Pleistocene fluvial deposits (e.g., RoHDE o THIEM 1998) and the occurrence of what appears to be Elsterian till in boreholes near Bünde, Bad Salzuflen and Vlotho (SKupin, SPEETZEN \& ZANDSTRA 2003).

The maximum extent of the Saalian ice cover in northwest Germany was reached during the older Saalian Drenthe ice advance ("Drenthe-Zeitz Phase"; cf. Litr et al. 2007). Ice lobes of this ice sheet intruded into the Münsterland Embayment, the Upper Weser Valley and Upper Leine Valley, damming the drainage pathways of rivers (e.g., Tноме 1983, 1998, Klostermann 1992, Herget 1998, Skupin, SPEETZEN \& ZANDSTRA 1993, 2003, EhLERs et al. 2004, Winsemann et al. 2007, 2009, Meinsen et al. in press). The second major ice advance of the Saalian glaciation (Warthian ice sheet) did not reach the study area (Fig. 1).

The blocking of the River Weser and River Leine Valley by the Drenthe ice sheet led to the formation of glacial lakes. The ice-dammed lake within the Upper Weser Valley is referred to as "glacial Lake Rinteln" (SPETHMANN, 1908), "glacial Lake Weserbergland" (KlostermanN 1992, Thome 1998) or "glacial Lake Weser" (Winsemann et al. 2009). Glacial Lake Rinteln refers to the northernmost part of the Upper Weser Valley, named by SpEthmANN (1908) after the small town of Rinteln. As the lake mainly occupied the Upper Weser Valley, the name "glacial Lake Weser" is the most appropriate designation and we suggest the continued use of this name. The ice-dammed lake in the Leine valley is referred to as "glacial Lake Leine" (e.g., Thome 1998, Winsemann et al. 2007).

During the last 100 years, numerous studies have been carried out in the Upper Weser and Upper Leine Valley to reconstruct the former ice-margins and map economically important ice-marginal and fluvial deposits. Detailed geological mapping (1: 25 000) of the Upper Weser Valley and Upper Leine Valley started at the beginning of the 20th century (1900-1930) and continued in the 1970s, 1980s and 1990s. More detailed studies were based on landform and provenance analysis of Pleistocene ice-marginal deposits, resulting in various depositional models, commonly assuming a subaerial formation of ice-marginal deposits (e.g., Siegert 1912, 1921, Grupe 1926, 1930, Soergel 1921, StACH 1930, 1950, LÜtTIG 1954, 1958, 1960, WoRTMANN 1968, Seraphim 1972, 1973, Rausch, 1975, 1977, Bombien 1987, Wortmann \& Wortmann 1987, Kaltwang 1992, Wellmann 1998, Feldmann 2002, Skupin, Speetzen \& ZANDSTRA 2003). 


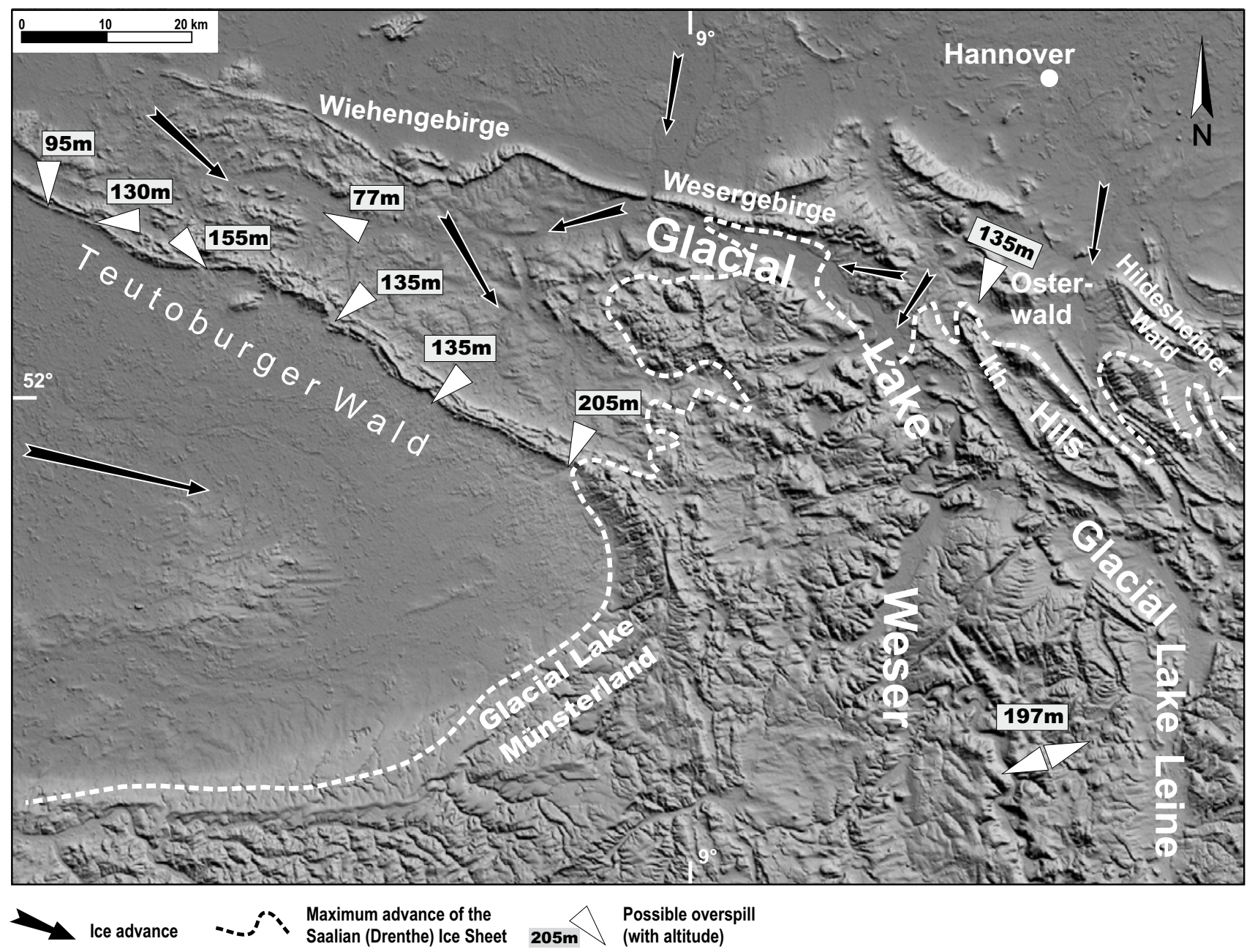

Fig. 2: The shaded relief map of the study area shows the maximum extent of the Saalian Drenthe ice sheet in the study area and major lake overspills. The digital elevation model is based on SRTM data. Modified after WINSEMANN et al. (2009).

Abb. 2: Digitales Höhenmodell des Untersuchungsgebietes mit der Position des maximalen Eisrandes und der Lage der wichtigen See-Überläufe. Das digitale Höhenmodell basiert auf SRTM Daten. Verändert nach WINSEMANN et al. (2009).

Re-examination of ice-marginal depositional systems, including a detailed analysis of the sedimentary facies, depositional processes, stratigraphic architecture and internal deformation patterns by WinSEMANN et al. (2003), WinSEMANN, Asprion \& MeYer (2004, 2007), HoRnung, Asprion \& Winsemann (2007), Winsemann et al. (2007, 2009), Brandes, Polom \& Winsemann (2011), Winsemann, Brandes \& Polom (2011) and Brandes et al. (2011) reveals that these depositional systems represent subaqueous fans and deltas deposited into glacial Lake Weser and glacial Lake Leine. Therefore, the principle lithologic evidence for large and deep glacial lakes in the Upper Weser Valley and Leine Valley is the occurrence of these subaqueous icemarginal deposits, which can be partly used as water-plane indicators. Boreholes logs and several clay pits record the widespread occurrence of more than $20 \mathrm{~m}$ of thick finegrained lake bottom sediments, overlying Middle Pleistocene fluvial deposits or bedrock.

The longevity of glacial Lake Weser and glacial Lake Leine can only be roughly estimated because varve deposits of the basin centre are only poorly exposed and no undisturbed core data are available. According to LitT et al. (2007) and Busschers et al. (2008), the Saalian Drenthe ice advance probably occurred during MIS 6 and lasted $\sim 5000$ years (LAMBECK et al. 2006). The longevity of the glacial lakes was probably very short, which has been estimated a few hundred to thousand years (JUNGE 1998, WinsemanN et al. 2009).

\section{Data Base and Methods}

A total of 27 sand and gravel pits and 4440 borehole logs were evaluated in order to document the regional pattern and character of Saalian glaciolacustrine deposits of the Upper Weser and Leine Valley (Fig. 2 and Fig. 3). Outcrop data are mainly available for the coarse-grained ice-marginal deposits, where sand and gravel has been excavated in numerous open pits. These outcrops were characterized from lateral and vertical measured sections across twoand three-dimensional exposures. The sections were measured at the scale of individual beds, noting grain size, bed thickness, bed contacts, bed geometry, internal sedimentary structures, and palaeocurrent directions. The spatial distribution of specific lithofacies was determined through detailed mapping of hand-drilled borings. The field study was supplemented with a georadar and shear-wave seismic 
survey. In addition, high-resolution digital elevation models were used to analyse geomorphological features of icemarginal deposits.

The maximum extent and derivative lake-level curve of glacial Lake Weser has been mainly defined by foreset-topset transitions of deltas and a sequence stratigraphic analysis of glaciolacustrine depositional systems (Winsemann, Asprion \& Meyer 2007, Winsemann et al. 2009, Winsemann, Brandes \& Polom 2011). Although the mapping of shoreline features is an important tool for reconstructing the palaeogeography and lake-level history of Late Pleistocene glacial lakes (e.g., Teller 1995, CARling et al. 2002, JoHNSEN \& BRENNAND 2006), this method does not work well with older Pleistocene lakes located in high relief areas, where shoreline features are likely to be destroyed or obscured by later periglacial processes and anthropogenic modification (e.g., LARoQue, Dubois \& LEBLON 2003).

The DEM was combined with information from geological maps (1: 25 000, 1: 100 000), outcrops and borehole logs to document the regional pattern and character of glaciolacustrine deposits in the Upper Weser and Leine Valley. Geographic Information Systems (GIS) were then used for the palaeogeographic reconstruction of glacial Lake Weser and glacial Lake Leine, superimposing water planes onto the land surface DEM.

\section{Palaeogeographic reconstruction of glacial Lakes in the Weser- and Leinebergland}

\subsection{Glacial Lake Weser}

During the maximum extent of the Drenthe ice sheet, glacial Lake Weser was dammed in the Upper Weser Valley along with major tributaries. The main spillway system of glacial Lake Weser is a series of valleys in the Teutoburger Wald Mountains over an altitude range of 40-205 $\mathrm{m}$ a.s.l. through which the proglacial lake drained south-westward (Tноме 1983, 1998, Klostermann 1992, Winsemann et al. 2009 and Winsemann, Brandes \& Polom 2011). These overspill channels increase in altitude towards the east (Fig. 2) and were successively closed during ice advance (Thome 1983, SKupIN, SPEETZEN \& ZANDSTRA 1993). On the eastern lake margin, two overspill channels are recognized. One is located in the gap between the Osterwald and Ith Mountains (Fig. 2). This potential overspill channel has an altitude of approximately $135 \mathrm{~m}$ and was probably closed early during ice lobe advance into the Weser and Leine Valley. Another overspill channel is located farther south at an altitude of $\sim 197 \mathrm{~m}$ a.s.l. This overspill channel is located east of Bodenfelde (Fig. 2 and Fig. 3) and is characterized by a $200-500 \mathrm{~m}$ wide, flat-floored valley that trends roughly east-west and cuts into Mesozoic bedrocks (e.g., Thome 1998, Winsemann et al., 2007). The valley is now occupied by two underfed rivers. The Schwülme River flows to the west into the Weser River and the Harste River flows to the east into the River Leine.

The principle lithologic evidence for a large and deep glacial lake in the Upper Weser Valley is the occurrence of subaqueous ice-marginal deposits, fine-grained lake bottom sediments, and ice-rafted debris far beyond the former ice margin. The stratigraphic evidence comes from both surface exposures and subsurface data. A total of 20 sand and gravel pits and 2300 borehole logs were evaluated in order to document the regional pattern and character of Middle Pleistocene deposits of the Upper Weser Valley. Outcrop data are mainly available for the coarse-grained ice-marginal deposits, where sand and gravel has been excavated in numerous open pits (WINSEMANN et al. 2003, WINSEMANn, Asprion \& MEYer 2004, 2007, Hornung, ASPRION \& WinSEMANN 2007, WinSEMANN et al. 2007, 2009 and WinsEMANN, Brandes \& POLOM 2011). The subsurface data come from borings drilled along the river valleys and tributaries. Borehole logs and several clay pits record the widespread occurrence of up to $20 \mathrm{~m}$ thick fine-grained lake bottom sediments ("Hauptbeckenton"), overlying Middle Pleistocene fluvial deposits of the Weser River („Mittelterrasse”) or bedrock (e.g., WinsEMANN et al. 2009). Former clay pits in the northern lake basin revealed that these lake-bottom sediments are commonly laminated and frequently contain dropstones (e.g., Rausch 1975, Kulle 1985, WellmanN 1998). These fine-grained lake-bottom sediments occur over an altitude range of 55 to $180 \mathrm{~m}$ a.s.l. Towards the south, the thickness of lake bottom sediments decreases $(<8 \mathrm{~m})$ and relics of lake-bottom sediments are mainly preserved along the valley sides (WINSEMANN et al. 2009).

Erratic clasts with a Scandinavian provenance occur within the entire study area (Fig. 3) and have been reported from altitudes of 114-200 m a.s.l. (e.g., Kaltwang 1992, FARRENSCHON 1995, RoHDE $\approx$ ThIEM 1998). These clasts frequently occur beyond the Drenthe ice-margin and therefore have been partly interpreted as relics of the Elsterian glaciation (e.g., Thiem 1988, Rohde $\mho$ Thiem 1998). New interpretations assume that these clasts represent ice-rafted debris dumped by icebergs. Clasts are commonly associated with fine-grained lake-bottom sediments or overly fluvial deposits. The occurrence in clusters at altitudes of $\sim 130 \mathrm{~m}$ and $\sim 185 \mathrm{~m}$ may indicate stranded icebergs at former lake shores (Winsemann et al. 2009). Associated beaches or shoreline features like wave-cut benches have not been recognized. It is not clear if beaches could have formed at the steep shores or if they have been destroyed or obscured by later periglacial processes and anthropogenic modification. It is also not known if glacial rebound affected the study area and played a major role in determining the position of former shorelines relative to today's surfaces of lake marginal depositional systems.

The maximum extent and derivative lake-level curve of glacial Lake Weser has been defined by foreset-topset transitions of deltas and a sequence stratigraphic analysis of glaciolacustrine depositional systems (WINSEMANN, BRANDES \& POLOM 2011). Disruption of drainage by ice advance created glacial Lake Weser at an altitude of $\sim 55 \mathrm{~m}$ a.s.l. The lake level then rose to a highstand $\sim 200 \mathrm{~m}$ a.s.l. caused by the successive closure of lake overspill channels (Fig. 4). Ice-marginal deposits of the north western lake margin (e.g., Markendorf delta and the ice-marginal deposits of the "Ravensberger Kiessandzug", cf. SKUPIN, SPEETZEN \& ZANDSTRA 2003) became deformed and overridden by the advancing ice sheet. During the maximum lake-level highstand of $\sim 200 \mathrm{~m}$ a.s.l., glacial Lake Weser was up to $150 \mathrm{~m}$ deep, covered an area of $\sim 1870 \mathrm{~km}^{2}$ and approximately $120 \mathrm{~km}^{3}$ of water was stored in the lake basin. The higher topographic position of ice-marginal deposits at the 
southwestern slope of the Thüster Berg Mountain southeast of Coppenbrügge (HERRMANN 1958) can be explained by a higher local lake-level of $\sim 215$ a.s.l. within the Hils syncline, which was completely dammed by ice and isolated from glacial Lake Weser and glacial Lake Leine during maximum ice sheet coverage.

The overall lake-level rise of glacial Lake Weser was followed by two high-amplitude lake-level falls (WINSEMANN, Brandes \& PolOM 2011). Opening of the $135 \mathrm{~m}$ and $95 \mathrm{~m}$ lake outlets in the Teutoburger Wald Mountains (Fig. 2) during ice-lobe retreat caused independent catastrophic lake-level drops in the range of 35-65 m (Fig. 4). The lake water drained into the Münsterland Embayment with a peak discharge of probably up to $1300000 \mathrm{~m}^{3} / \mathrm{s}$. During these outburst events, deep plunge pools, streamlined hills and trench-like channels were cut into Mesozoic bedrock and Pleistocene deposits (MEINSEN et al. in press). Subsequently, a lake-level rise in the range of $30 \mathrm{~m}$ occurred, caused by a new ice-lobe advance into the Münsterland Embayment ("Hondsrug ice stream" cf. van den BERG \& BeEts 1987, Skupin, SpeEtzen \& Zandstra 1993), leading to the renewed closure of the $95 \mathrm{~m}$ overspill channel in the Teutoburger Wald Mountains and the observed lake-level rise (Fig. 4). Rapid destabilization of this ice-lobe led to the final drainage of the Weser Lake.

\subsection{Glacial Lake Leine}

During the maximum extent of the Drenthe ice sheet, an icedammed lake developed within the Upper Leine and Rhume Valley, referred to as "glacial Lake Leine" (Thоме 1998, WinsEmann et al. 2007). The main spillway system of glacial Lake Leine is the overspill channel in the gap between the Osterwald and Ith Mountains at an altitude of approximately $135 \mathrm{~m}$ a.s.l. and the broad, east-west trending valley east of Bodenfelde at $\sim 197 \mathrm{~m}$ a.s.l. Thick accumulation of fine-grained lake-bottom sediments at the eastern valley outlet (JoRDAN 1984) may indicate a preferred overflow from glacial Lake Weser into glacial Lake Leine (Fig. 3), although the contour lines of the overspill channel may also point to a temporal westward-directed overflow from glacial Lake Leine into glacial Lake Weser. A third overspill channel is located on the northeastern margin of glacial Lake Leine, connecting the Leine Lake with the Nette Valley (Fig. 3). This overspill channel also has an altitude of $\sim 200$ $\mathrm{m}$ and more than $20 \mathrm{~m}$ thick accumulation of fine-grained lake-bottom sediments in front of the western channel outlet (e.g., JORDAN 1993) points to mainly south westward-directed overflows from the Nette Lake into the Leine Lake.

As in the Weser Valley, the principle lithologic evidence for a large and deep glacial lake in the Upper Leine Valley is the occurrence of subaqueous ice-marginal deposits and fine-grained lake bottom sediments. Some isolated erratic clasts with a Scandinavian/Baltic provenance have been described from the area near Ahlshausen south east of Bad Gandersheim and been interpreted to represent relics of an Elsterian glaciation (JoRDAN \& SCHWARTAU 1993). However, these clasts may also represent ice-rafted debris dumped by icebergs. A total of 7 sand and gravel pits and 2140 borehole logs were evaluated in order to document the regional pattern and character of Middle Pleistocene deposits in the
Upper Leine Valley. Borehole logs record the widespread occurrence of up to $20 \mathrm{~m}$ thick fine-grained lake bottom sediments within the entire study area over an altitude range of 80-190 $\mathrm{m}$ a.s.l. (Fig. 3). The maximum thickness of lake-bottom deposits is recorded west of Northeim and Nörten-Hardenberg, where up to $50 \mathrm{~m}$ of fine-grained sediments have been drilled (e.g., JoRDAN 1984, 1986). This area belongs to a complex pull-apart basin system that evolved during the late Cretaceous (Vollbrecht \& TANner in press) and provided the accommodation space.

The age of the fine-grained lake sediments of the Upper Leine Valley is poorly constrained. They are commonly overlain by late Pleistocene fluvial or aeolian deposits and partly overlie Upper Pleistocene fluvial deposits ("Mittelterrasse), pointing to a Saalian age. However, the sediments have not been absolutely dated and it is possible that thick successions of fine-grained lake bottom sediments may also comprise older Middle and Lower Pleistocene deposits (e.g., JoRDAn 1984, 1986, 1993).

The lake-level history of glacial Lake Leine has not been reconstructed in detail. Recently a new field study supplemented with a shear-wave seismic survey was carried out to reconstruct the palaeogeographic evolution and lakelevel history of glacial Lake Leine (WAHLE et al. 2010). The palaeogeographic reconstruction of the Leine Lake shown in Figure 3 is based on well data and mapped glaciolacustrine ice-marginal deposits. During highstand, glacial Lake Leine probably reached a lake-level of $\sim 200 \mathrm{~m}$ a.s.l. as is indicated by the topographic position of glaciolacustrine ice-marginal deposits and fine-grained lake bottom sediments, corresponding with a lake area of $\sim 900 \mathrm{~km}^{2}$, a water volume of up to $\sim 36 \mathrm{~km}^{3}$ and a water depth of up to $\sim 90 \mathrm{~m}$. During deglaciation the ice probably rapidly retreated northwards, indicated by northward-stepping small beadlike sediment bodies (LÜTTIG 1960, JoRDAN 1989). A new ice margin stabilized in front of the Osterwald and Hildesheimer Wald Mountains, which acted as a pinning point.

\section{Depositional Archtitecture of Glaciolacustrine ice- marginal deposits}

\subsection{Glacial Lake Weser}

Three major subaqueous fan and delta complexes are recognized on the northern margin of glacial Lake Weser, which can be related to the ice-front position of the Drenthe ice sheet. From east to west, these are the Porta subaqueous fan and delta complex, the Emme delta, and the Coppenbrügge subaqueous fan complex (Fig. 3).

\subsubsection{The Porta subaqueous fan and delta complex}

The Porta ice-margin deposits are located south of the Porta Westfalica pass, which has an altitude of $42 \mathrm{~m}$. Deposits were well-exposed in numerous sand and gravel pits (Fig. 5) and have previously been described by several authors. Most previous workers assumed a subaerial morainal, glaciofluvial, kame or fluvial origin for the Porta ice-margin deposits (e.g., KoKen 1901, Struck 1904, Spethmann 1908, Siegert 1912, Driever 1921, Naumann 1922, Grupe 1930, Stach 1930, Grupe ET AL. 1933, MiotKe 


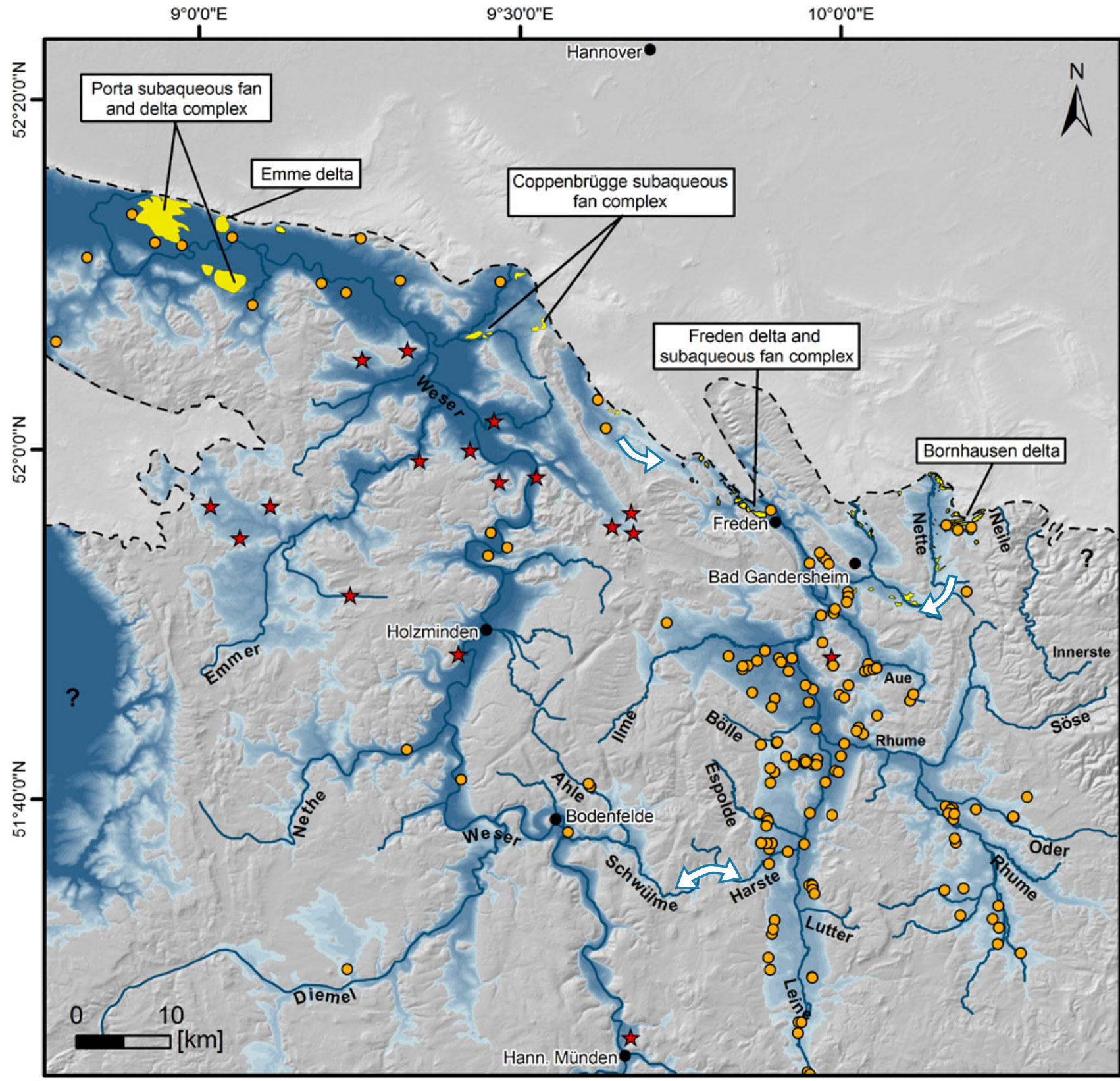

\section{Water depth $[\mathrm{m}]$}

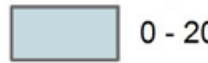

$0-20$
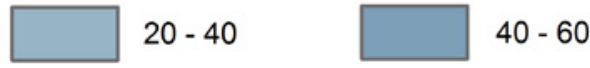

$40-60$

$60-80$

$>80$

\section{Glaciolacustrine deposits}

Subaqueous fan

and delta deposits

Fine-grained lake
bottom sediments

次 Ice-rafted debris

$\leadsto$ Overspill

\section{- - - - The inferred location of the ice-margin associated with the maximum level of glacial Lake Weser and glacial} Lake Leine ( 200m a.s.I.)

Fig. 3: Detail map of the study area, showing a palaeogeographic reconstruction of glacial Lake Weser and glacial Lake Leine and associated ice-marginal depositional systems, ice-rafted debris and lake-bottom sediments. Data are compiled from map sheets 1: 25 000, outcrop data and wells.

Abb. 3: Detail-Karte des Untersuchungsgebietes mit der paläogeographischen Rekonstruktion des Weser- und Leine-Eisstausees. Dargestellt sind die assoziierten Eisrand-Ablagerungssysteme, erratische Blöcke und feinkörnige Becken-Ablagerungen. Die Daten wurden aus geologischen Karten (1: 25 000), Aufschlüssen und Bohrungen kompiliert.

1971, Seraphim 1973, Deutloff et al. 1982, Röhm 1985, Groetzner 1995, Könemann 1995, Wellmann 1998, ElBRACHT 2002).

Re-examination of outcrops by HORNUNG, ASPRION \& Winsemann (2007), Winsemann, AsPrion \& MEYER (2007) and WinsemanN et al. (2009) reveal a subaqueous origin for the Porta ice-margin deposits. Several sedimentary characteristics indicative of subaqueous deposition were recorded. Data critical to this re-interpretation include the recognition of jet-efflux deposits, turbidites, ice-rafted debris dumped by icebergs, and Gilbert-type delta deposits.

These coarse-grained ice-marginal deposits overlie $0.3-20 \mathrm{~m}$ 


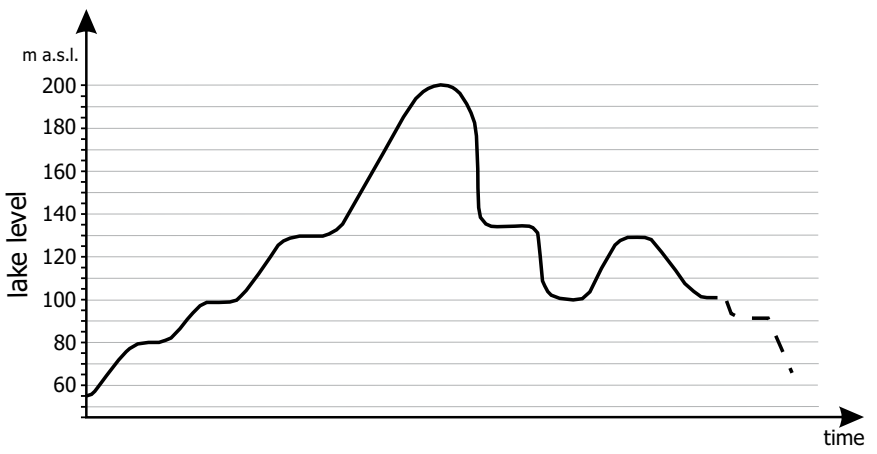

Fig. 4: Reconstructed lake-level curve of glacial Lake Weser. Modified after WinSEMANN, BRANDES \& POLOM (2011). The longevity of glacial Lake Weser can only be roughly estimated and has probably been a few hundred to thousand years.

Abb. 4: Rekonstruktion der Seespiegelkurve des Weser-Eisstausees (verändert nach WiNSEMANN, BRANDES \& POLOM 2011). Die Lebensdauer des Sees kann nur grob abgeschätzt werden und betrug vermutlich nur wenige 100 bis 1000 Jahre.

thick glaciolacustrine mud and patchy occurrences of till (KöNEMANN 1995, Wellmann 1998, Winsemann et al. 2009). Clasts consist mainly of local material derived from the adjacent Mesozoic basement rocks and reworked fluvial gravel, previously deposited by the Weser River. Clasts with a Scandinavian and/or Baltic provenance account for 2-12 \% (Röhm 1985, WellmanN 1998). Southward palaeoflow directions and clast composition indicate that meltwater flows were the main source of sediment (WINSEMANN et al. 2009).

Three fan complexes can be recognized (Fig. 5), deposited on a flat lake-bottom surface and characterized by vertically and laterally stacked, moderately- to steeplydipping sediment bodies. The northernmost fan body is unconformably overlain by two generations of Gilbert-type deltas (Winsemann et al. 2009). The extent, morphology, clast composition and sedimentary facies indicate deposition into a lake at the margin of the retreating Porta ice lobe. The ice lobe retreat was probably caused by the overall lake-level rise (Fig. 4) that led to a destabilisation of the ice margin. The ice-margin eventually became re-stabilized near the Porta Westfalica pass, where a stable meltwater tunnel facilitated the construction of a large subaqueous fan and delta complex.

\section{Fan complex I}

The stratigraphically lowest fan (fan complex I, Fig. 5) is up to $60 \mathrm{~m}$ thick and consists of moderately to steeply dipping mid-fan deposits, characterized by graded-stratified sand and channelized large-scale trough cross-stratified sand and gravel. These mid-fan deposits unconformably overlie flatlying planar cross-stratified proximal fan gravel (WINSEMANN, ASPRION \& MEYER 2007a). The sedimentary sequence is partly deformed, displaying thrusts, dipping towards the northwest and overlain by flow till and glaciolacustrine mud (WeLlmanN 1998). Towards the south the fan deposits interfinger with dropstone laminites (RAUSCH 1975).

\section{Fan complex II}

Fan complex II (Fig. 5) consists of $9 \mathrm{~m}$ thick massive, normally graded or large-scale trough-cross stratified proximal fan gravel, unconformably overlain by $15 \mathrm{~m}$ thick mod- erately- to steeply-dipping distal mid-fan deposits, characterized by medium- to thick-bedded inversely graded, massive, diffusely stratified pebbly sand or normally graded sand to mud beds. This succession shows an overall finingand thinning upward trend.

\section{Fan complex III}

Fan complex III is exposed in several gravel pits south of the Porta Westfalica pass (Fig. 5). To determine the largerscale architecture of the northern Porta complex, shear wave seismic reflection profiles have been acquired and analyzed (Fig. 6 and Fig. 7). The greatest thickness of fan deposits is recorded from a central, $\sim 1 \mathrm{~km}$ wide and $5.4 \mathrm{~km}$ long, NWSE trending zone (Fig. 6 and Fig. 7). Deposits, exposed in this central zone consist of highly scoured massive, normally graded, planar-parallel or cross-stratified gravel, interpreted to have been deposited from a friction-dominated plane-wall jet at the mouth of a subglacial meltwater tunnel (HoRNUNG, AsPrion \& WinsEmAnn 2007, Winsemann et al. 2009). Subsequent flow-splitting led to the development of smaller jets at the periphery of this bar-like deposits and the deposition of more sand-rich jet-efflux deposits characterized by largescale trough-cross stratified gravel, pebbly sand and sand (Fig. 7B and C).

During the subsequent high-magnitude lake-level drops (Fig. 4), the subaqueous fan became truncated and overlain by delta deposits. Two different Gilbert-type deltas can be recognized, which were formerly exposed in the Müller 2 and Hainholz pit (Fig. 5, Fig. 6 and Fig. 7B). These deltas are separated by a major erosional unconformity. The first delta generation is characterized by steep and coarse-grained delta foreset beds, deposited from cohesionless debris flows and high- to low-density turbidity currents, indicating a steep high-energy setting (Fig. 7B and D). These delta deposits resembles those exposed in the Emme delta and are unconformably overlain by finer-grained delta sediments, deposited mainly from tractional flows and representing a shallower, lower-energy setting and the formation of a larger delta plain (Fig. 7E) during the subsequent lake-level rise (Fig. 4).

\section{Internal deformation pattern}

The deformation of the Porta deposits includes both contractional and extensional structures. The observed north-westward dipping thrusts within Fan complex I (WELLMANN 1998) record glaciotectonic deformation of previously deposited ice-margin sediments, probably related to seasonal ice-margin fluctuations. A simple graben system is developed in the Mesozoic basement rocks below the central fan area (Fig. 7B). Single normal faults propagate into the overlying Pleistocene deposits, indicating a Pleistocene reactivation of Upper Triassic to Lower Jurassic deformation structures. Within the coarse-grained central fan deposits, a series of steep normal faults are recorded, which are restricted to the fan body. These are not related to the basement tectonics and therefore are interpreted as compactional or gravitational deformation features. Larger-scale delta channel-fills, previously exposed in the Müller 2 pit (Fig. 5) show high-angle (65-90 $)$ gravitational synsedimentary normal faults (vertical offset 0.1-1.2 $\mathrm{m}$ ), which are parallel to the channel-margins. This 


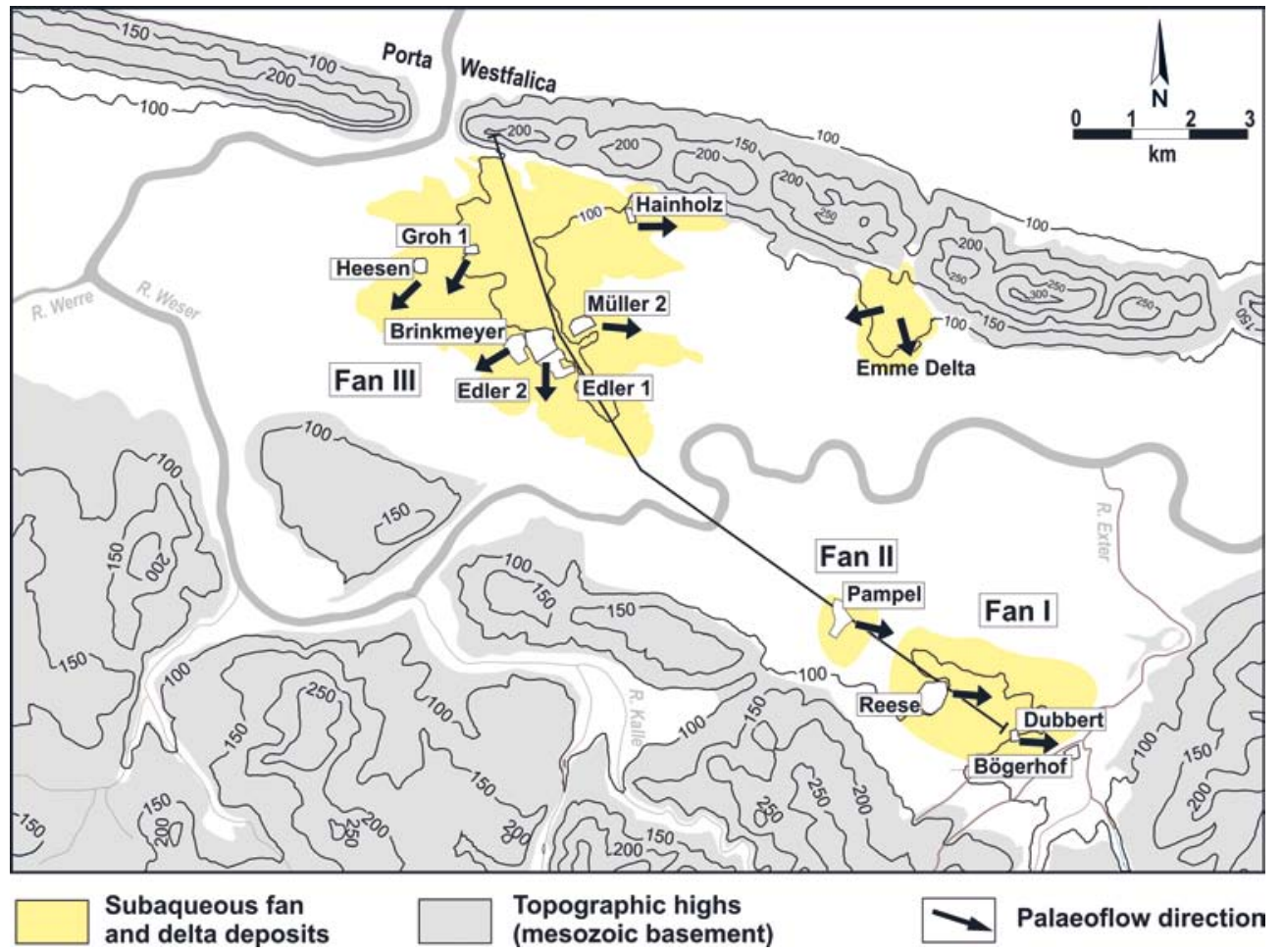

Fig. 5: Location of the Porta complex and the Emme delta. Modified after WINSEMANN et al. (2009).

Abb. 5: Lage des Porta Komplexes und des Emme Deltas. Verändert nach WINSEMANN et al. (2009).

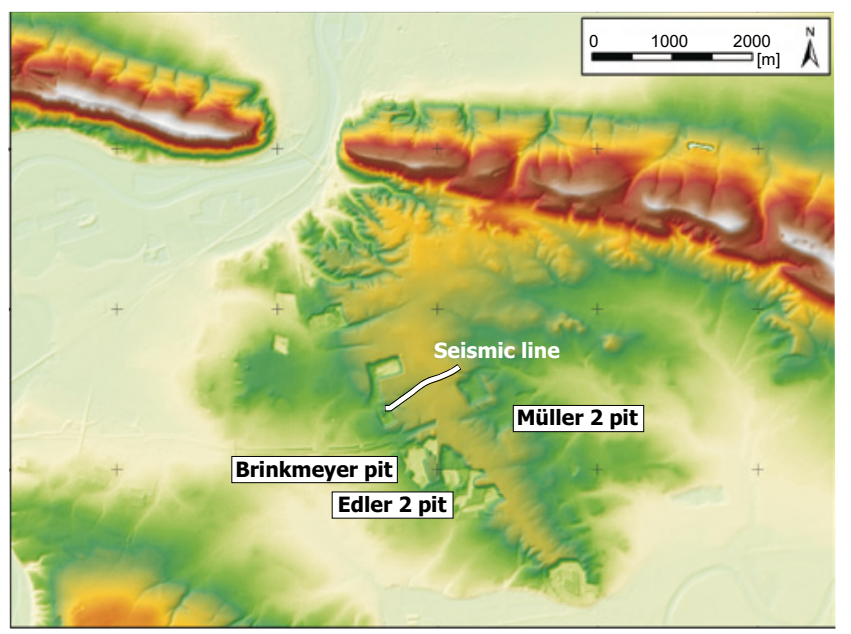

Fig. 6: Hill-shaded relief model of the northern Porta complex (fan complex III), showing the location of the shear-wave seismic profile. The digital elevation model is based on data from the Landesvermessungsamt NordrheinWestfalen.

Abb. 6: Digitales Höhenmodell des nördlichen Porta Komplexes (fan complex III) mit der Lage des Scherwellen-Seismik Profils. Das digitale Höhenmodell basiert auf Daten des Landesvermessungsamts Nordrhein-Westfalen.

kind of gravitational deformation is known from many marine deep-water channel-levee systems (e.g., CLARK \& Pickering 1996, Moretti et al. 2003).

\subsubsection{The Emme delta}

The Emme deposits are located south of the Kleinenbremen pass, which has an altitude of $\sim 153 \mathrm{~m}$. The radial sediment body is about $2 \mathrm{~km}$ long, $1.8 \mathrm{~km}$ wide and up to $70 \mathrm{~m}$ thick, overlying a concave, up to $13^{\circ}$ steep dipping ramp surface. The sediment body has a stepped profile with two plains at $\sim 128 \mathrm{~m}$ and $\sim 155 \mathrm{~m}$ a.s.l. The upper portion is characterized by a central, trumpet-shaped, up to $20 \mathrm{~m}$ deep valley that rapidly shallows downslope (Fig. 8).

The deposits were well-exposed in several sand and gravel pits over an altitude range of 95-165 $\mathrm{m}$ and have previously been described by several authors who assumed a subaerial kame or alluvial fan formation (GRUPE 1930, Stach 1930, Attig 1965, MiotKe 1971, Hesemann 1975, Merkt 1978, RAKowski 1990 \& Groetzner 1995). Clasts mainly consist of poorly sorted, angular local material derived from steep Mesozoic bedrock slopes. Clasts with a Scandinavian / Baltic provenance account for approximately 10\% (RAKowsKi 1990). More recently the Emme deposits were interpreted as a delta (THOME 1998, JAREK 1999, WiNSEMANn, Asprion \& Meyer 2004, Winsemann, Brandes \& Polom 2011).

The data derived from outcrop analysis suggests Gilberttype delta sedimentation (Winsemann, Asprion \& Meyer 2004, Winsemann, Brandes \& Polom 2011). High-angle bedding and coarse-grained foreset deposits indicate steep slopes with gravity driven flows. Material that bypassed the braid plain avalanched downslope as cohesionless debris flows and was deposited en-masse when the slope diminished. The finer-grained sandy material moved farther downflow where it was deposited from diluted debris flows and turbidity flows. Topset deposits in outcrop sections have mostly been eroded and are only locally preserved as channel-fills, overlying truncated delta foresets (WinsemanN, BRANDES \& POLOM 2011).

To determine the larger-scale architecture of the Emme delta complex, 3 shear wave seismic reflection profiles have been acquired and analyzed. The seismic sections show a complex pattern of 9 vertically and laterally stacked depositional units (Fig. 9). The oldest depositional units are vertically stacked, decreasing upwards in thickness and lateral extent. These depositional units are incised by an up to $150 \mathrm{~m}$ wide and $20 \mathrm{~m}$ deep incised valley and fringed 

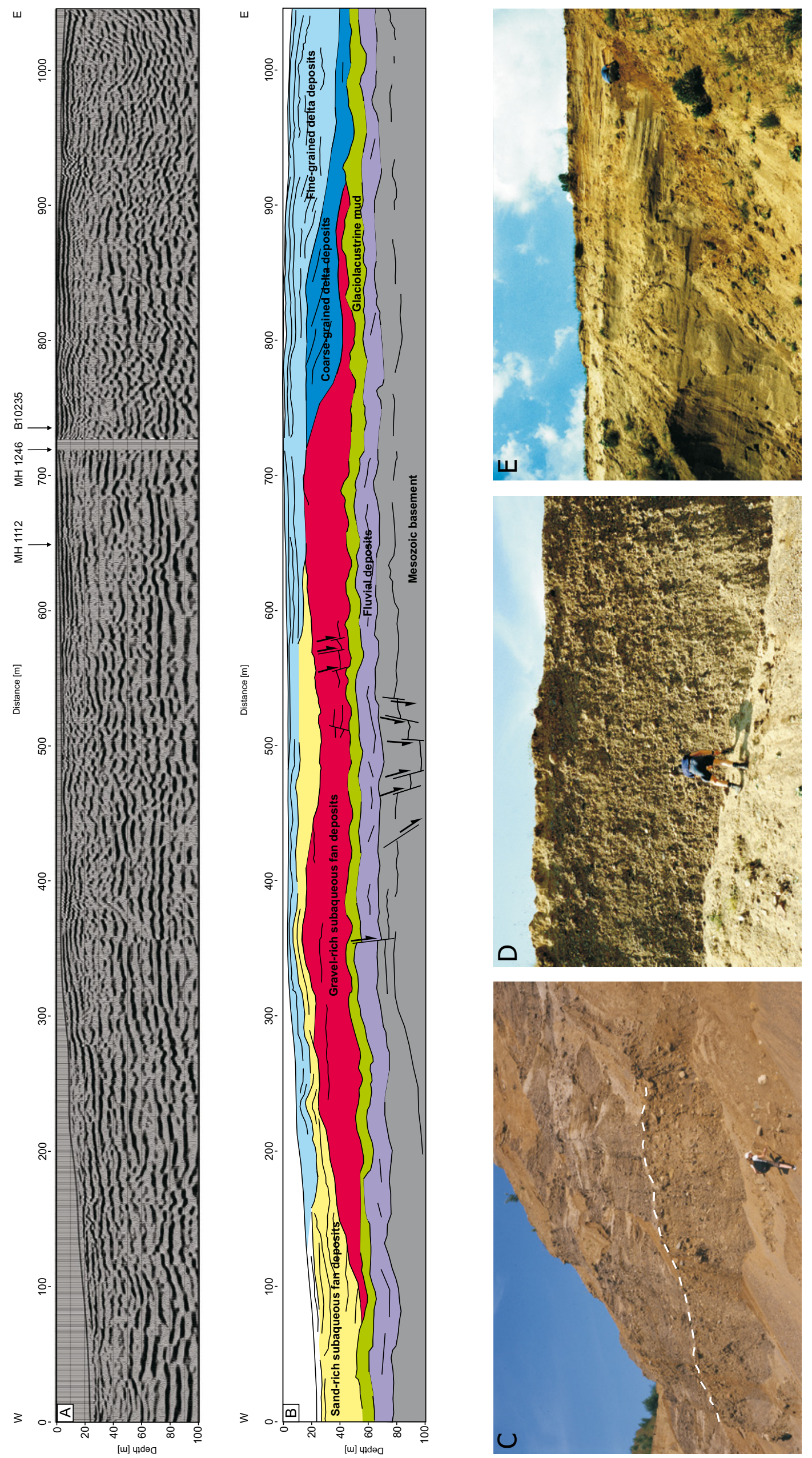

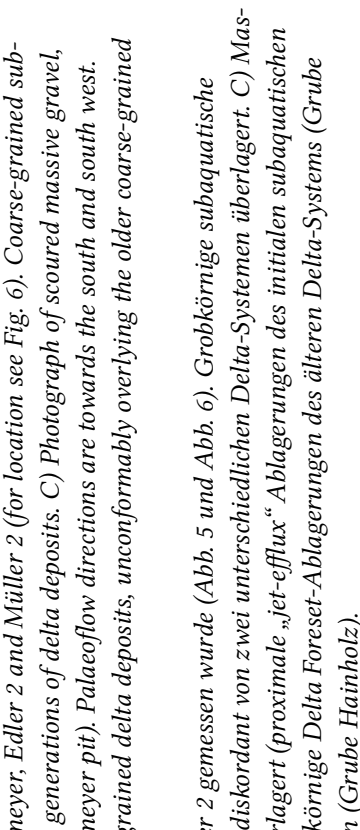

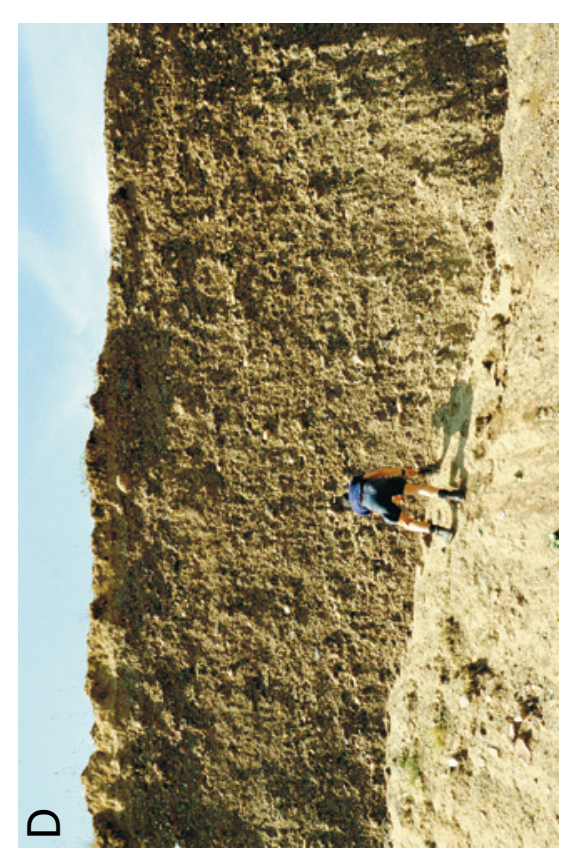

है है है

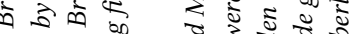

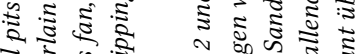

है

क० ₹

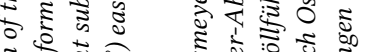

है

कृ इ

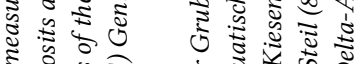

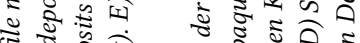

कृष

ชั)

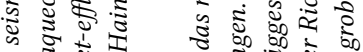

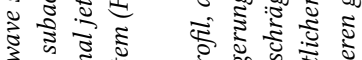

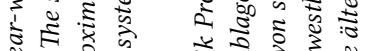

के

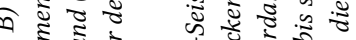

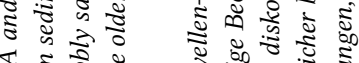

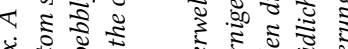

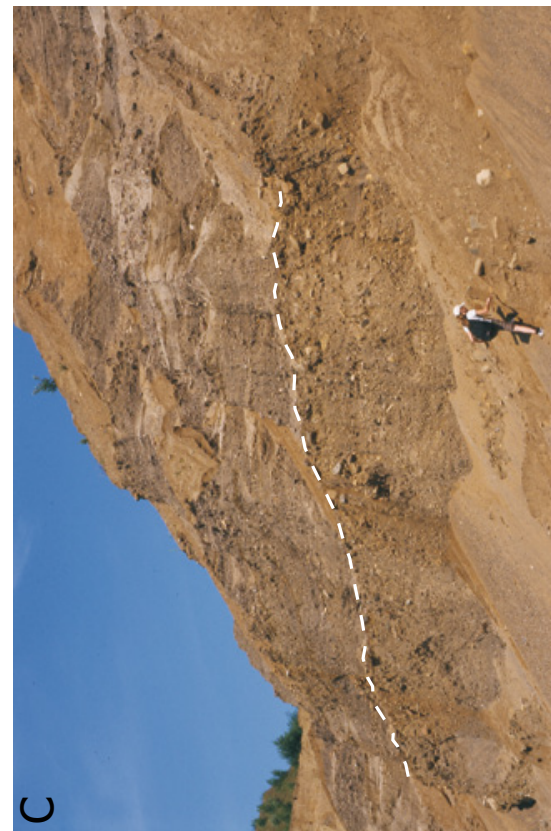

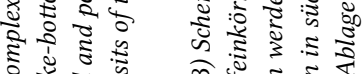

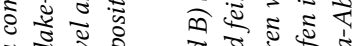

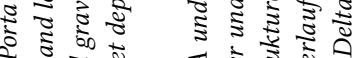

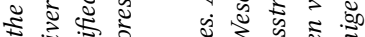

के के है

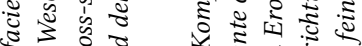

हैँ

चूँ

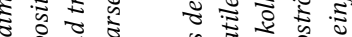

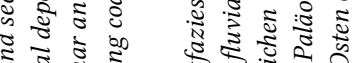

क०

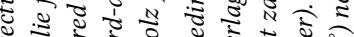

₹

ड

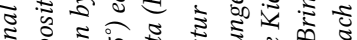

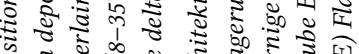

के

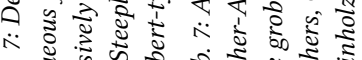

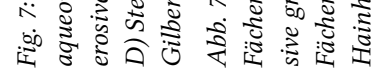


by younger, basin ward-stepping units. The youngest features are long-wavelength $(60-80 \mathrm{~m})$ bedforms on the south eastern portion of the delta, which erosively overlie the delta lobe deposits and pass downslope into subhorizontal and inclined continuous, high-amplitude reflectors (unit 9). This complex stacking pattern is attributed to delta lobe switching during progradation and base-level change (Winsemann, Brandes of Polom 2011). During the overall lake-level rise, vertically stacked delta systems formed. The decrease in thickness and lateral extent indicates a rapid upslope shift of depocenters. The facies distribution during rapid, high-magnitude lake-level fall ( $\sim 5 \mathrm{~m})$ was controlled by the formation of a single incised valley, which captured the sediment and focussed the sediment supply to regressive lobes in front of the incised fairway, as shown in numerical simulations by Ritchie, GAWTHORPE \& HARDY (2004 a). The incised valley was filled due to delta plain/glaciofluvial aggradation during decreasing rates of lake-level fall and lake-level lowstand. This matches results from flume tank experiments, carried out by PetTer \& Muto (2008) for systems where the alluvial gradient exceeds the shelf gradient, as conceptualized by various authors (e.g., PosAmentier, Allan \& James 1992, Schumm 1993, Blum \& Törnqvist 2000). Attached sand-rich forced regressive aprons formed during lower magnitudes of lake-level fall in the range of $35 \mathrm{~m}$. The formation of attached aprons has been attributed to low rates of lake-level fall or a rapid fall associated with high sedimentation rates, causing only minor incision (e.g., Ritchie, Gawthorpe \& Hardy 2004 a, b). In the case of the Emme delta, rates of lake-level fall were high due to the opening of lake outlets. Deep valley incision occurred, but was limited to the uppermost portion of the delta, controlled by the steep slope. The incised valley was probably filled during lake-level lowstand and lake-level rise. However, the valley was never flooded during transgression and the shoreline remained basinward of the incised valley. The incised valley related to the final lake drainage is associated with long-wavelength (60-90 m) bedforms at the downslope end, attributed to the formation of antidunes and standing waves as a result of a hydraulic jump. The calculated palaeoflow depth during standing wave formation was 9-14 m and flow velocity was $10-12 \mathrm{~m} / \mathrm{s}$ (WINSEMANN, BRANDEs $\circlearrowright$ PolOM 2011).

The stepped geomorphological profile of the Emme delta is the result of vertically and laterally shifting delta lobes during lake-level fluctuations. However, it seems to be very difficult to define discrete lake-levels from geomorphology alone (e.g., Tноме 1998), because it is not possible to reconstruct the complex depositional history.

\section{Internal deformation pattern}

In the Emme delta, two different fault systems developed, both showing synsedimentary activity (Fig. 9). The faults have planar to slightly listric geometries and show vertical offsets in the range of 2 to $15 \mathrm{~m}$. They form small graben and half-graben systems, which locally show roll-over struc-
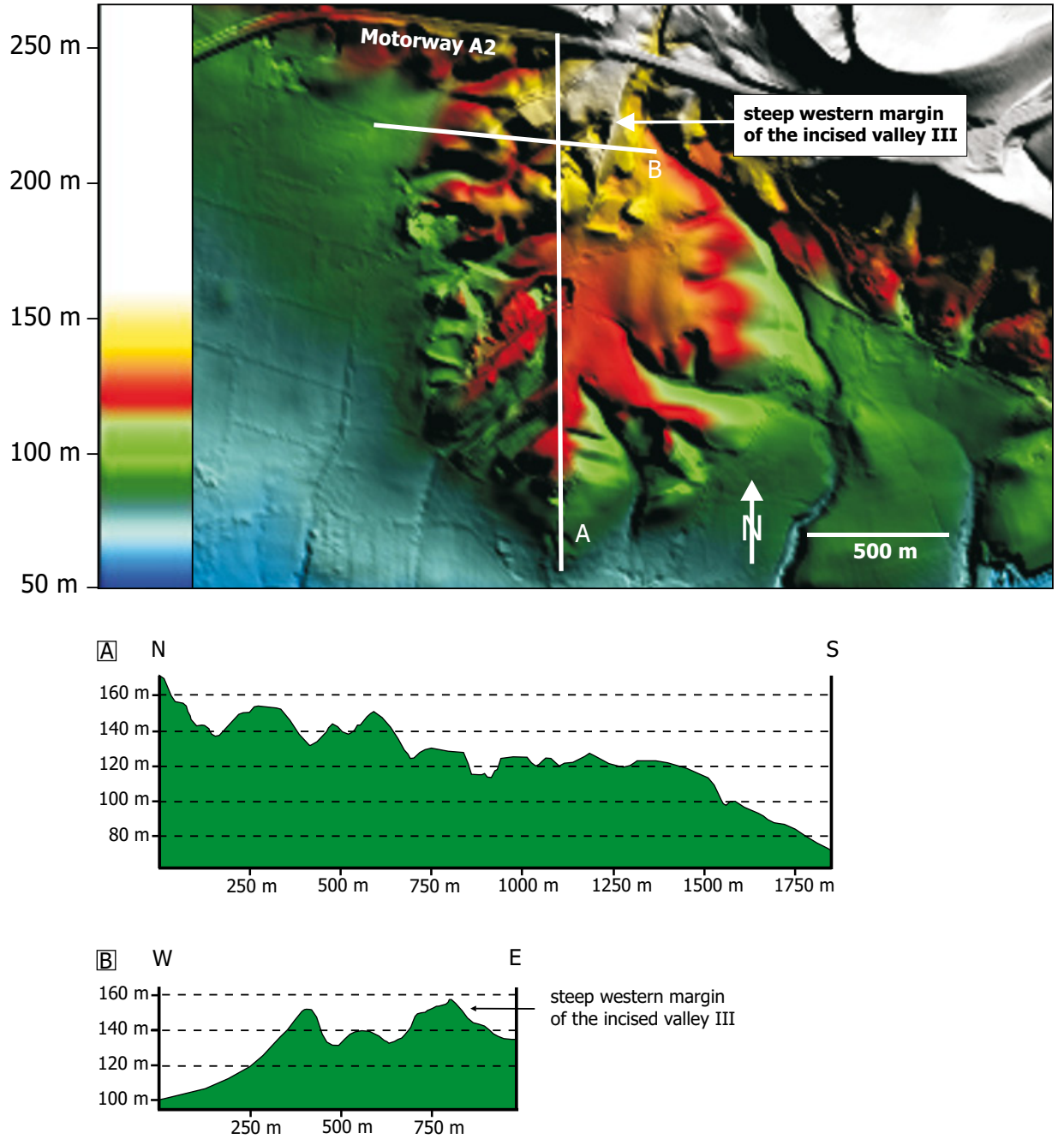

Fig. 8: Hill-shaded relief model of the Emme delta. Cross-sections show the stepped profile of the Emme delta with two plains at $\sim 128 \mathrm{~m}$ and $\sim 155 \mathrm{~m}$. Note the steep western margin of the central incised valley. The digital elevation model is based on data from the Landesvermessungsamt Nordrhein-Westfalen. Modified after WINSEMANN, BRANDES \& POLOM (2011).

Abb. 8: Digitales Höhenmodell des Emme Deltas. Die Schnitte zeigen den steilen westlichen Rand des zentralen Tales (,,incised valley III") sowie das gestufte Profil des Emme Deltas mit zwei ausgeprägten Niveaus auf einer Höhe von $128 m$ und $\sim 155 \mathrm{~m}$ ü. NN. Das digitale Höhenmodell basiert auf Daten des Landesvermessungsamts Nordrhein-Westfalen. Verändert nach WINSEMANN, BRANDES \& POLOM (2011). 

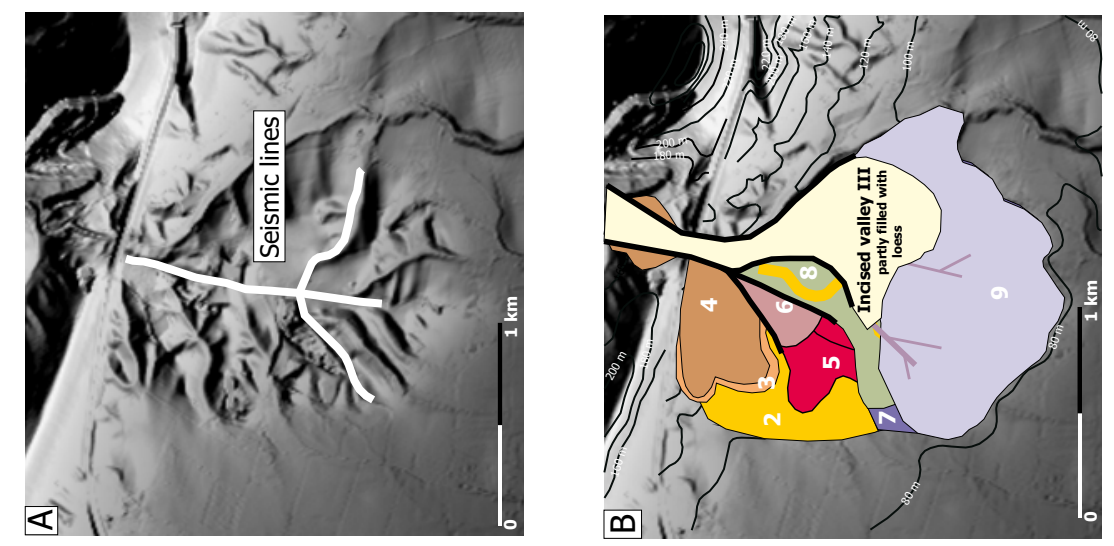

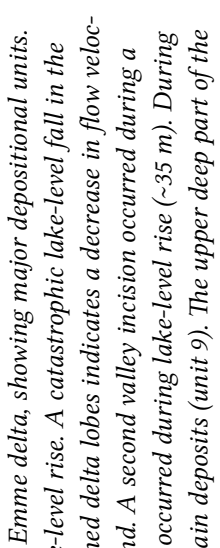

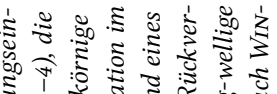

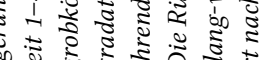

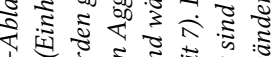

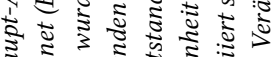

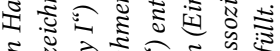

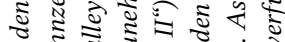

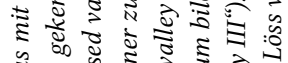

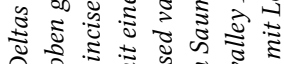

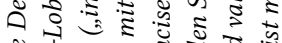

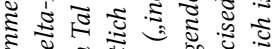

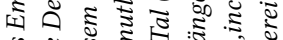

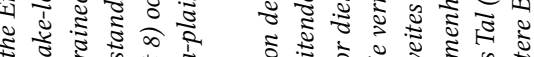

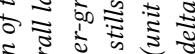

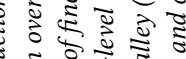

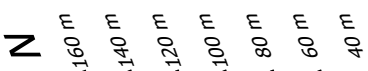

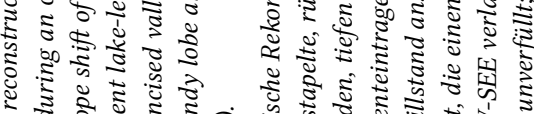

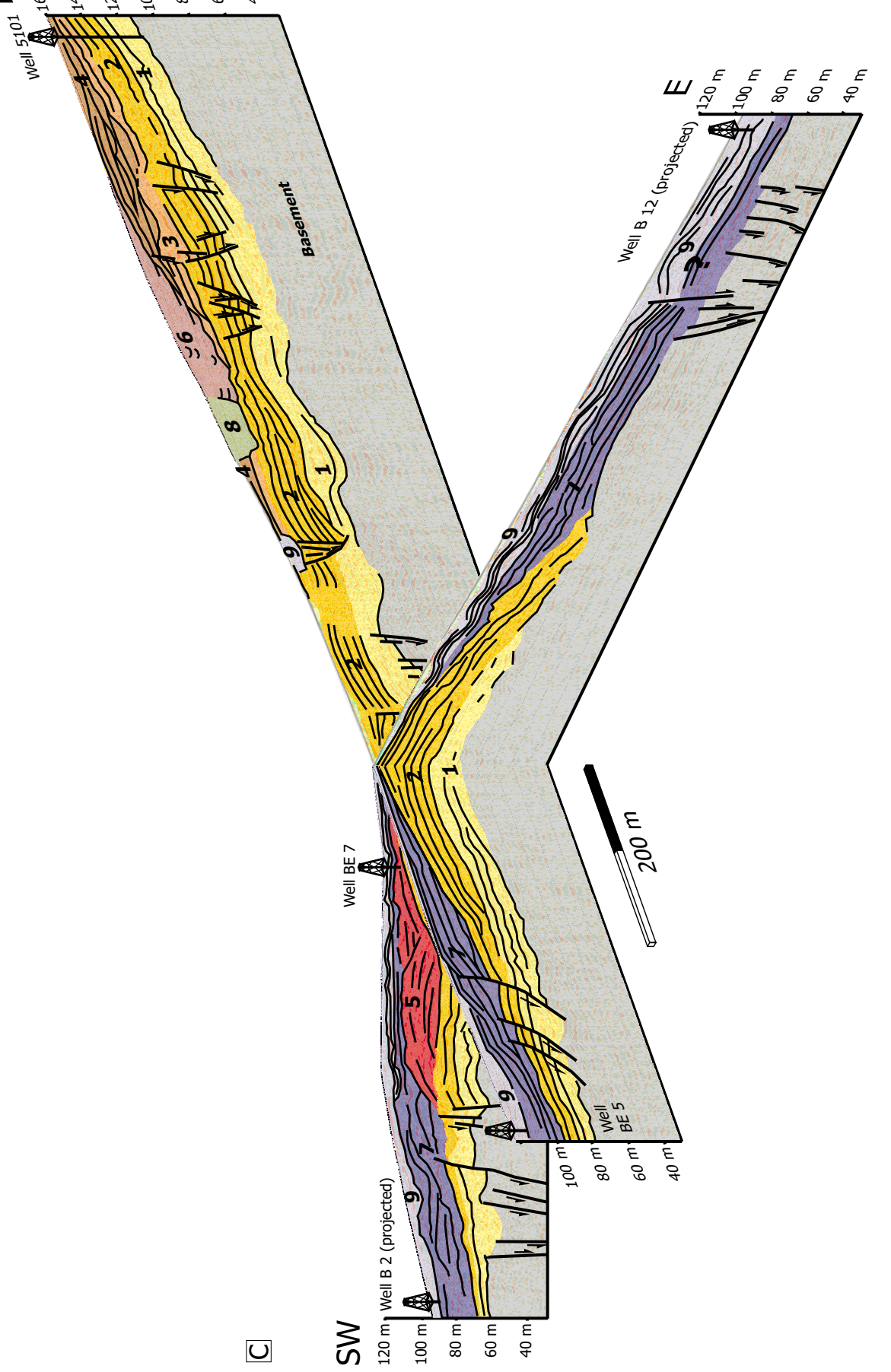

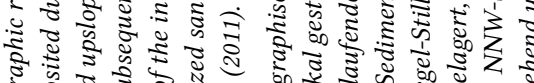

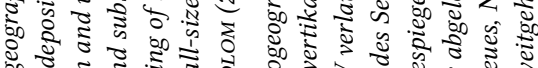

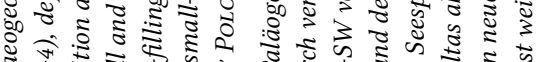

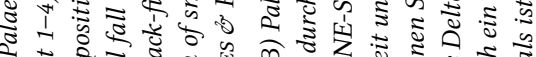

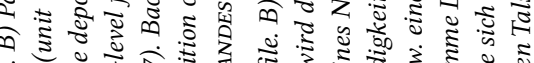

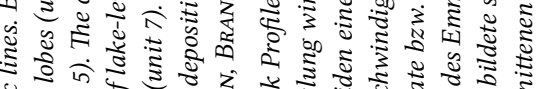

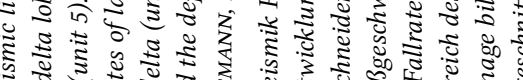
कर

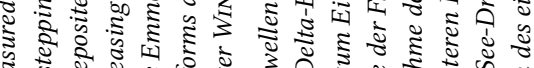
ปั

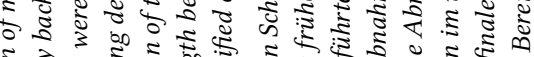

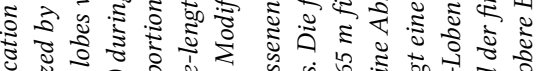
ชั.

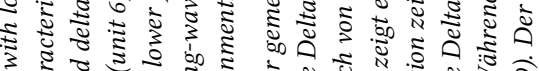

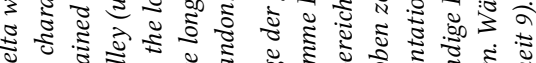

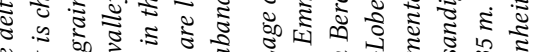

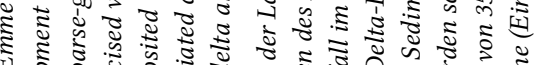

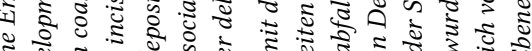

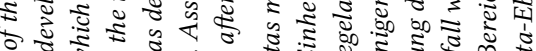

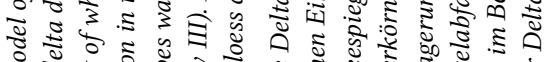

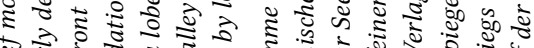

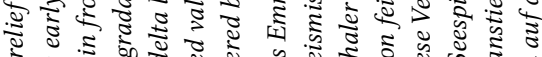

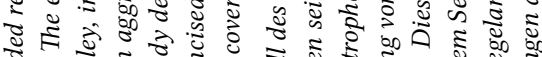
व.

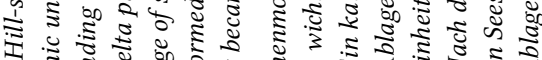

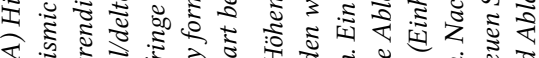

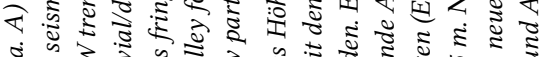

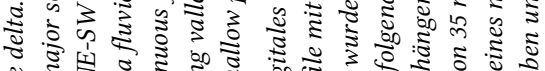

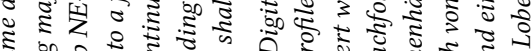
हิ

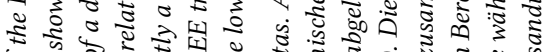
จ

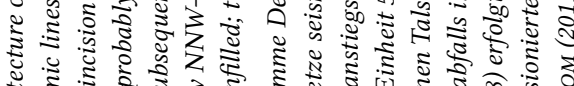

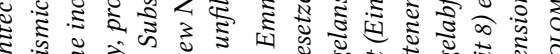

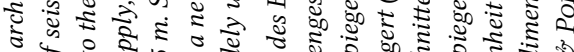

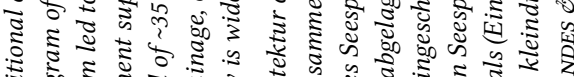

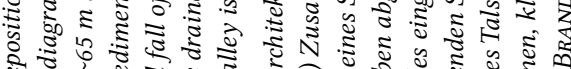

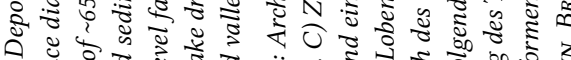
Whin 
tures. The fill of the half-grabens has a wedge-shaped geometry, with the greatest sediment thickness close to the fault (Brandes, Polom \& Winsemann 2011). The fault system in the upper portion of the Emme delta is restricted to the delta body and probably gravity induced like in many other deltas (e.g., Bilotti \& SHAw 2005). In the lower portion of the delta, however, normal faults occur that originate in the underlying Jurassic basement rocks and penetrate into the delta deposits. The trend of these faults follows extensional structures created by a Late Triassic to Early Jurassic deformation phase. It is very likely that these faults were reactivated during the Pleistocene.

\subsubsection{The Coppenbrügge subaqueous fan complex}

The Coppenbrügge fan complex is located on the northeastern margin of glacial Lake Weser and consists of 3 smallscale sediment bodies (Fig. 10), deposited on a hummocky low-angle basin slope. The deposits were exposed in various gravel pits over an altitude range of 90-170 m and overlie glaciolacustrine mud and a diamicton, interpreted to represent a basal till (DETERs 1999). Clasts consist mainly of resedimented fluvial material (95\%), previously deposited by the Leine River and Weser River or originated from adjacent Mesozoic bedrock (RAusch 1977, Deters 1999). Most previous field studies have assumed a subaerial end moraine, glaciofluvial kames or fluvial origin for the Coppenbrügge deposits (Grupe 1930, NAumann 1927, NAumanN \& Burre 1927, LÜtTig 1954, 1960, Rausch 1977, Deters 1999, ELBRACHT 2002).

Re-examination of outcrops by MEYER (2003), WinSEMANN et al. (2003) and Winsemann, Aspion \& Meyer (2004, 2007) suggests a subaqueous origin for the Coppenbrügge ice-margin deposits. Several sediment characteristics indicative of subaqueous deposition were recorded. Data critical to this re-interpretation include the recognition of subaqueous jet- efflux deposits, turbidites, thick climbing-ripple cross-laminated units, ice-rafted debris dumped by icebergs and the occurrence of an iceberg scour. The lack of any subaerial glaciofluvial or distributary delta-plain components and the frequent occurrence of ice-rafted debris point to a subaqueous ice-contact fan setting (e.g., LøNNE, 1995).

The retrogradational fan bodies accumulated from an easterly and northerly direction as several small subaqueous fans, indicating small conduits with minor effluxes which more easily mix with lake water, so constraining the distance of sediment dispersal (e.g., FyFE 1990, Powell 1990). Bedrock highs acted as pinning points for the retreating glacier. The stratigraphic record indicates a retreat of active ice, which occurred by calving.

The stratigraphically lowest fan system overlies lakebottom sediments and was exposed in the Otto pit at an altitude of $84-100 \mathrm{~m}$. The deposits are partly overlain by a basal till and display thrusts, dipping to the east, probably indicating ice-margin fluctuations during overall retreat (Winsemann, Asprion \& Meyer 2007).

Fan II overlies a basal till and is exposed at an altitude of 144-155 a.s.l. at the open-pit HBT and Heerburg. Fan III was exposed at an altitude of 143-165 $\mathrm{m}$ at the open-pit Heerburg and pit Steinbrink (Fig. 10). On top of fan III, a prominent iceberg scour mark occurred (Fig. 11A and D), overlain by coarsening-upwards mid-fan deposits. The overall coarsening upwards of the uppermost section indicates the progradation of a new fan system (Fan IV) from the east.

Individual fan bodies commonly have a coarse-grained proximal core of steeply dipping upper fan gravel, disconformably overlain by sandy outer- to mid-fan deposits. Climbing-ripple cross-laminated and large-scale cross-stratified sand may onlap coarse-grained upper fan gravel of stratigraphic lower fan bodies and in some cases overtops the older fan deposits (Fig.11). Deposits of the proximal fan

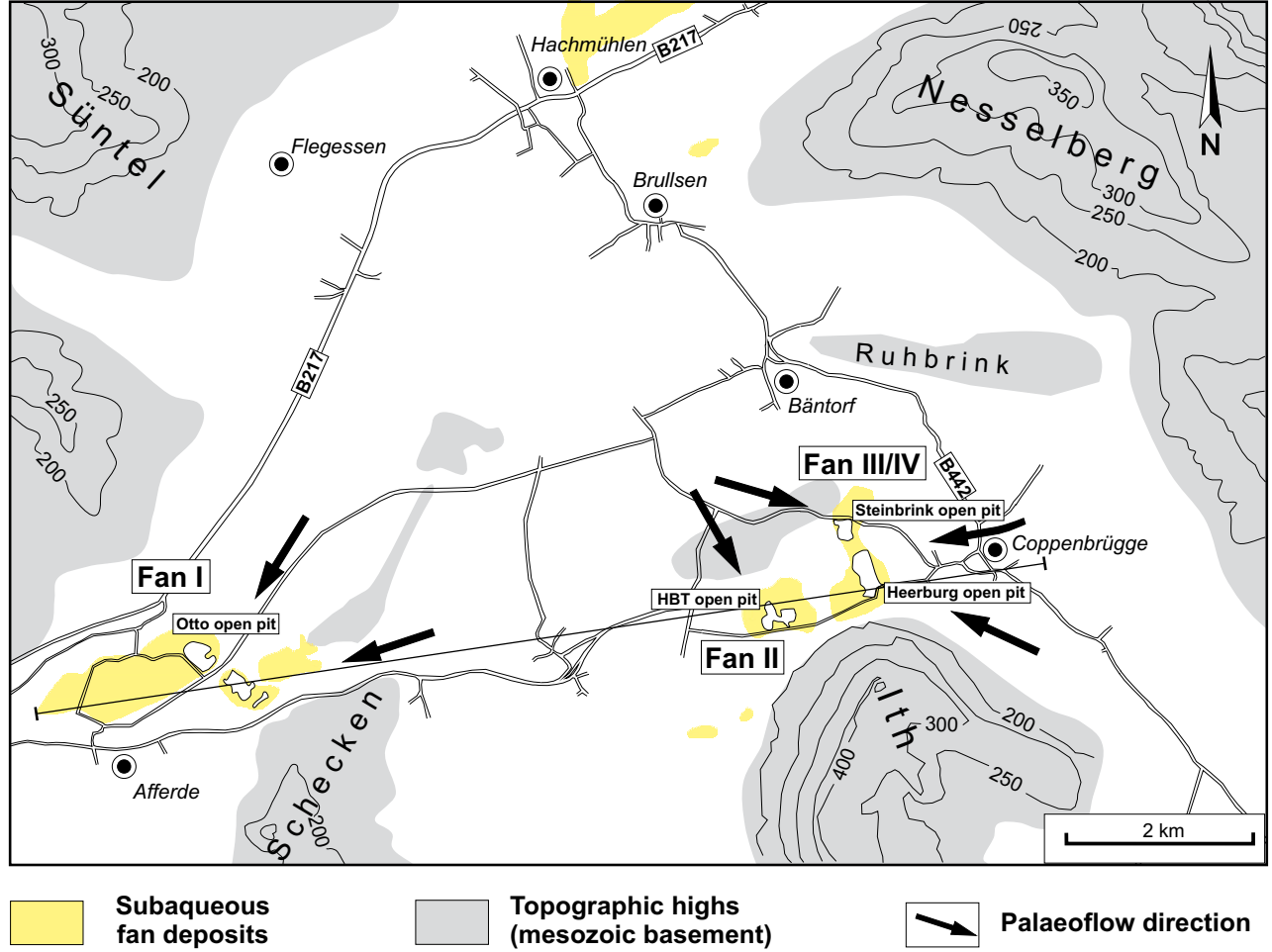

Fig. 10: Location of the Coppenbrügge subaqueous fan. Modified after WINSEMANN, ASPRION \& MEYER (2007).

Abb. 10: Lage des subaquatischen Coppenbrügge Fächers. Verändert nach WINSEMANN, ASPRION \& MEYER (2007). 

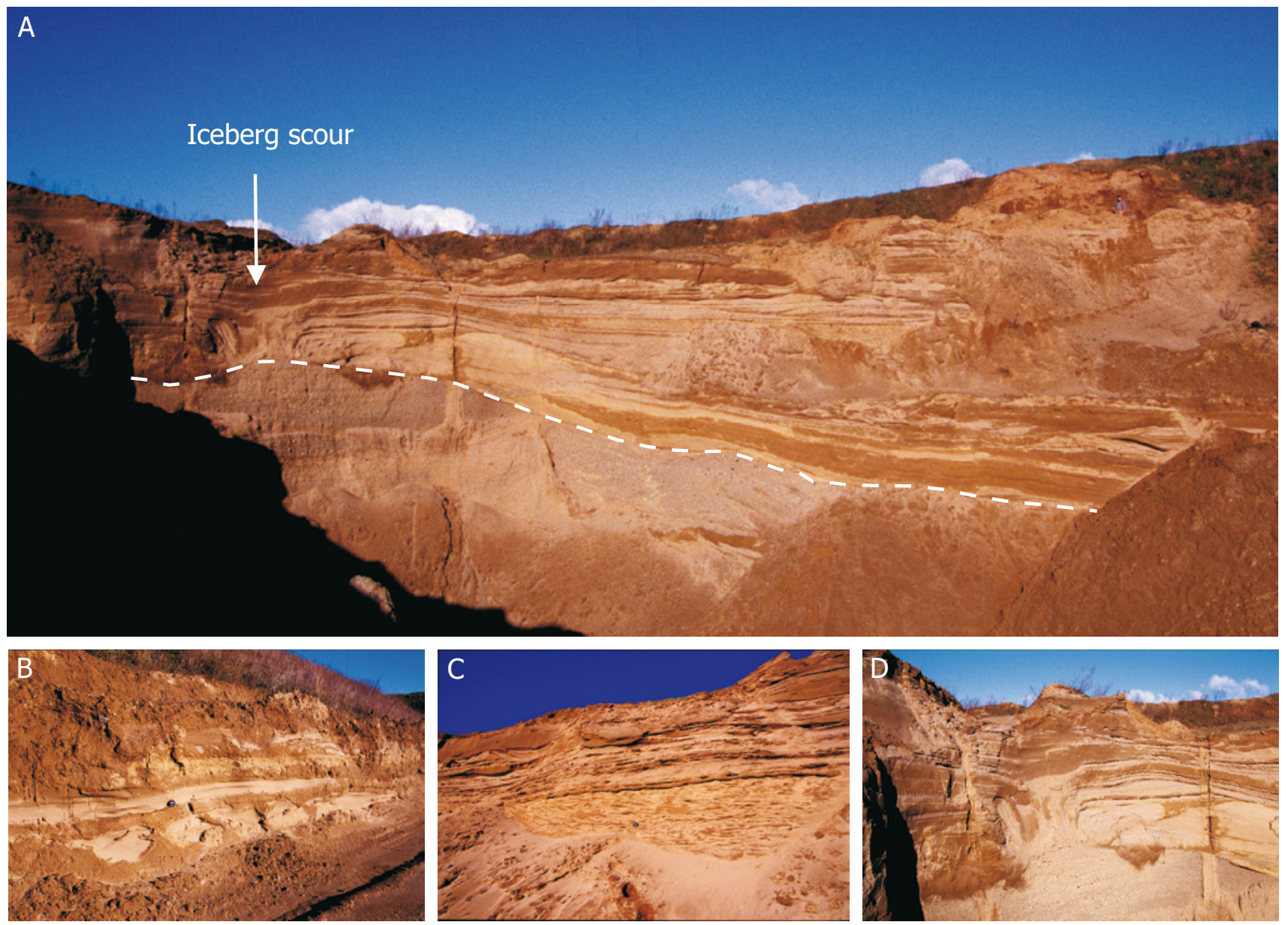

Fig.11: Depositional architecture and sedimentary facies of the Coppenbrügge subaqueous fan. A) Coarse-grained upper fan deposits, unconformably overlain by finer-grained outer- to mid-fan deposits recording a rapid ice-margin retreat and deposition on the back-slope of the abandoned fan. Note iceberg scour on top of the abandoned fan. B) Close-up view of fine-grained lower-fan deposits with ball and pillow structures, indicating high sedimentation rates. C) Close-up view of climbing-ripple cross-laminated sand; ripples migrate upslope. D) Close-up view of the iceberg scour on top of the abandoned fan. The scour is approximately $1.5 \mathrm{~m}$ deep and up to $1.5 \mathrm{~m}$ wide.

Abb. 11: Architektur und Sedimentfazies des subaquatischen Coppenbrügge Fächers. A) Grobkörnige Ablagerungen des oberen Fächers, werden diskordant von feinerkörnigen Ablagerungen des äußeren und mittleren Fächers überlagert. Dies zeigt einen schnellen Eisrückzug an, der mit Ablagerungen auf dem rückseitigen Hang des verlassenen Fächers verbunden war. Am Top des Fächers ist eine Eisberg-Erosionsstruktur zu sehen. B) Nahaufnahme der feinkörnigen Ablagerungen des äußeren Fächers mit Ball- und Kissenstrukturen, die hohe Sedimentationsraten anzeigen. C) Nahaufnahme der sandigen Ablagerungen mit Kletterrippeln. Die Kletterrippeln migrieren hangaufwärts. D) Nahaufnahme der Eisberg-Erosionsstruktur am Top des Fächers. Die Erosionsstruktur ist etwa 1,5 $\mathrm{m}$ tief und bis zu 1,5 m breit.

core are distinctly coarse grained with relatively few sand or silt beds. Beds mainly consist of cross-bedded clast-supported pebble- to cobble-sized gravel with a fine- to coarsegrained sand matrix, which may contain scattered clasts of diamicton. Beds are often highly scoured. This coarsegrained cross-bedded upper fan gravel is interpreted to represent mouth-bar clinoforms indicating rapid deposition and progradation at an ice-marginal conduit. Deposits are texturally mature and therefore mainly represent resedimented outwash material. Slope failure and renewed sediment discharge from the tunnel mouth fed gravity flows that transported sediments radially away from the margin. Deposits of the mid-fan slope consist of massive, planar-parallel stratified, or cross-stratified pebbly sand and climbing-ripple cross-laminated sand alternating with channelized massive or normally graded gravel and pebbly sand. Towards the distal mid-fan and outer-fan slope multiple stacked climbing-ripple-cross-laminated sand units or alternations of finegrained sand, silt, and mud occur, in which individual beds fine upwards. Scattered pebbles can frequently be observed and are mainly concentrated in mud layers. The lack of subaerial topset facies demonstrates that the retreat was probably fast and that fans did not reach the contemporary waterlevel (Winsemann, Asprion \& Meyer 2007).

\section{Internal deformation pattern}

The deformation of the Coppenbrügge fan deposits includes both contractional and extensional structures. The lowermost fan is characterized by eastward dipping thrusts, recording glaciotectonic deformation of previously deposited ice-margin sediments (Winsemann, Asprion \& Meyer 2004). Most commonly normal faults are developed. As in the Porta complex, normal faults are developed within the fan deposits and large-scale channel-fills show high-angle synsedimentary normal faults, which are parallel to the channel-margins and are interpreted as gravitational deformation (e.g., Clark \& Pickering 1996, Moretti et al. 2003). 


\subsection{Glacial Lake Leine}

The southernmost occurrences of Middle Pleistocene icemargin deposits are recorded from the Leine and Nette Valley near Freden, Bad Gandersheim, Seesen and Bornhausen (Fig. 3), which can be related to the ice front position of the Drenthe ice sheet (e.g., Harms 1984, Thiem 1972, FELDmAnN 2002). These ice-marginal deposits occur over an altitude range of approximately 140-200 m a.s.l. Two subaqueous fan and delta complexes can be defined from outcrop analysis. These are the Freden subaqueous fan and delta complex and the Bornhausen delta. Deposits near Bad Gandersheim and Seesen have not been excavated in major pits and no outcrop data are available.

\subsubsection{The Freden subaqueous fan and delta complex}

The Freden ice-margin deposits are located on the western margin of the Leine Valley and form part of a larger icemarginal complex that were formerly exposed in several pits between Freden and Imsen (Fig. 12). The deposits are up to $60 \mathrm{~m}$ thick and directly overlie Mesozoic basement rocks. HARMs (1983, 1984) described a general decrease in grain size from north to south and mean palaeoflow directions towards southerly and easterly directions. Glaciotectonic deformation and the occurrence of flow till point to an ice-contact setting (Harms 1983, 1984, FeldmanN \& Groetzner 1998). The deposits have been mapped over an altitude range of approximately 140-200 m a.s.l. (HARMs 1983, 1984) and described by several authors. Most previous workers assumed a subaerial end moraine or kame formation (e.g., Wermbter 1891, Müller 1896, von Koenen \& MÜller 1900, Schwarzenbach 1950, Lüttig 1954, 1960, Harms 1983, 1984, Kaltwang 1992, LATZKe 1996, Feldmann \& Groetzner 1998, Feldmann 2002), whereas Tноме (1998) proposed a subglacial origin for the Freden deposits. A detailed work on the diagenesis of carbonate concretions within the Freden deposits has been carried out by ELBRACHT (2002). Clasts consist mainly of local material derived from the adjacent Mesozoic basement rocks or resedimented fluvial material, previously deposited by the Leine River. Clasts with a Scandinavian/Baltic provenance have an average proportion of $16 \%$ and may reach up to $25 \%$ in flow till layers (HARMs 1984, LATZKe 1996).

Most gravel pits have been refilled today but the large Ulrich open-pit near Freden allowed a detailed re-examination of sections (MEYER 2003, WinSEMANN et al. 2007, BrANDES et al. 2011). Deposits formerly exposed near Imsen were described by HARMs $(1983,1984)$. These deposits are commonly rich in gravel and associated with till layers. Palaeoflow directions are to the northeast and southeast (Fig. 12).

The Freden ice-margin deposits are exposed at an altitude of $140-173 \mathrm{~m}$ and are characterized by several vertically and laterally stacked moderately to steeply dipping sediment bodies, which differ in sedimentary facies, facies associations and the overall geometry. The oldest sediments are exposed in the eastern part of the open pit. Dip and palaeoflow directions are mainly towards northeasterly and southeasterly directions. The analysis of sedimentary facies indicates that these ice-margin deposits have been deposited by subaqueous gravity flows. The occurrence of ice-rafted debris and flow-till points to an ice-contact subaqueous fan setting (WinsEMANN et al. 2007). From this part of the section, large-scale deformation structures have also been reported (Feldmann \& Groetzner 1998, FELDMANN 2002), probably indicating an unstable ice margin, where short-term oscillations caused glaciotectonic deformation (PowELL 1990, LøNNE 1995, 2001). Upper fan deposits consist of steeply dipping $\left(16^{\circ}-20^{\circ}\right)$ massive gravel deposited from cohesionless debris flows. Towards the distal upper-fan zone, intercalations of diffusely, planarparallel, or planar cross-stratified pebbly sand increase, in-

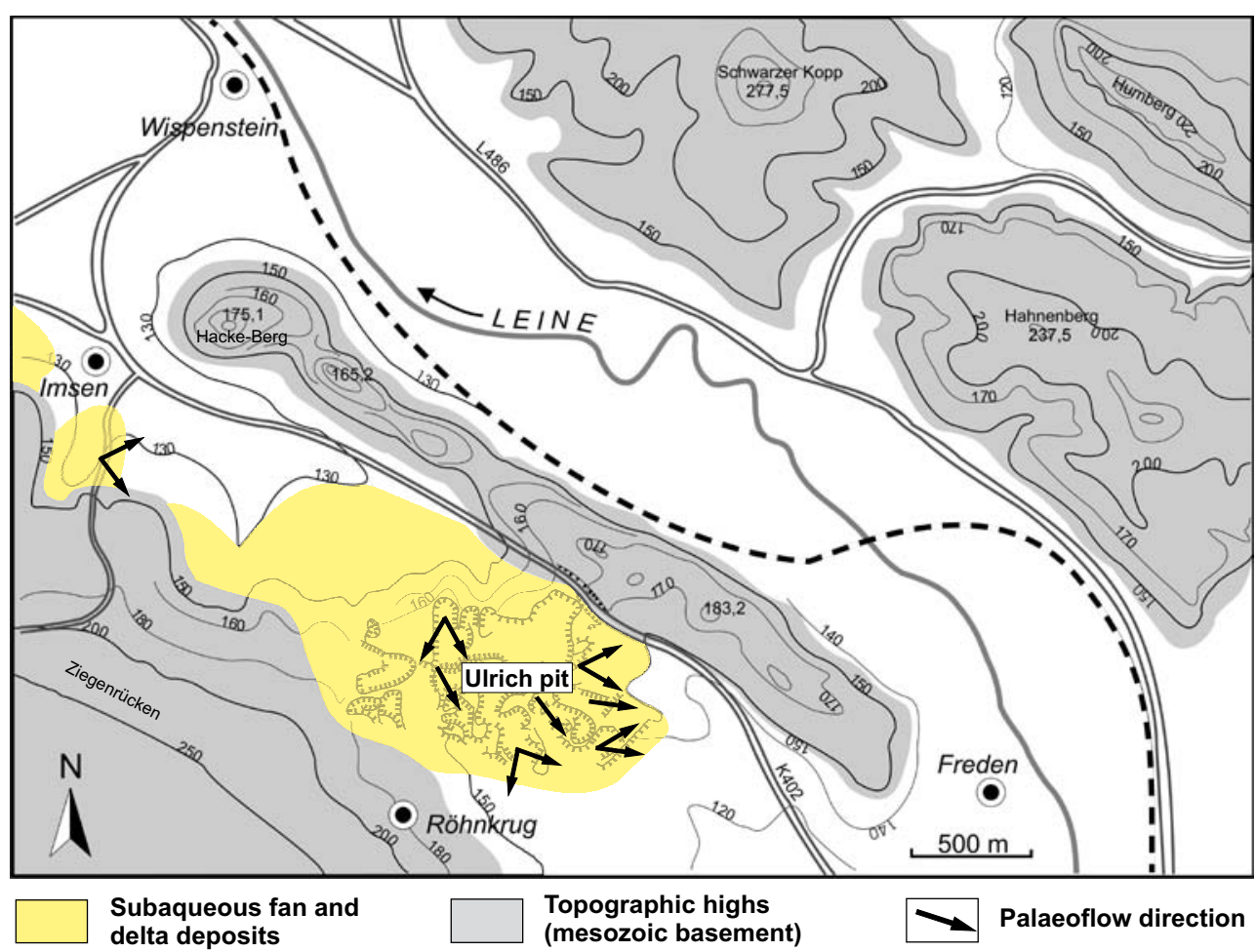

Fig. 12: Location of the Freden subaqueos fan and delta complex. Modified after WINSEMANN et al. (2007). Abb. 12: Lage des Freden Fächer- und Delta-Komplexes. Verändert nach WINSEMANN et al. (2007). 

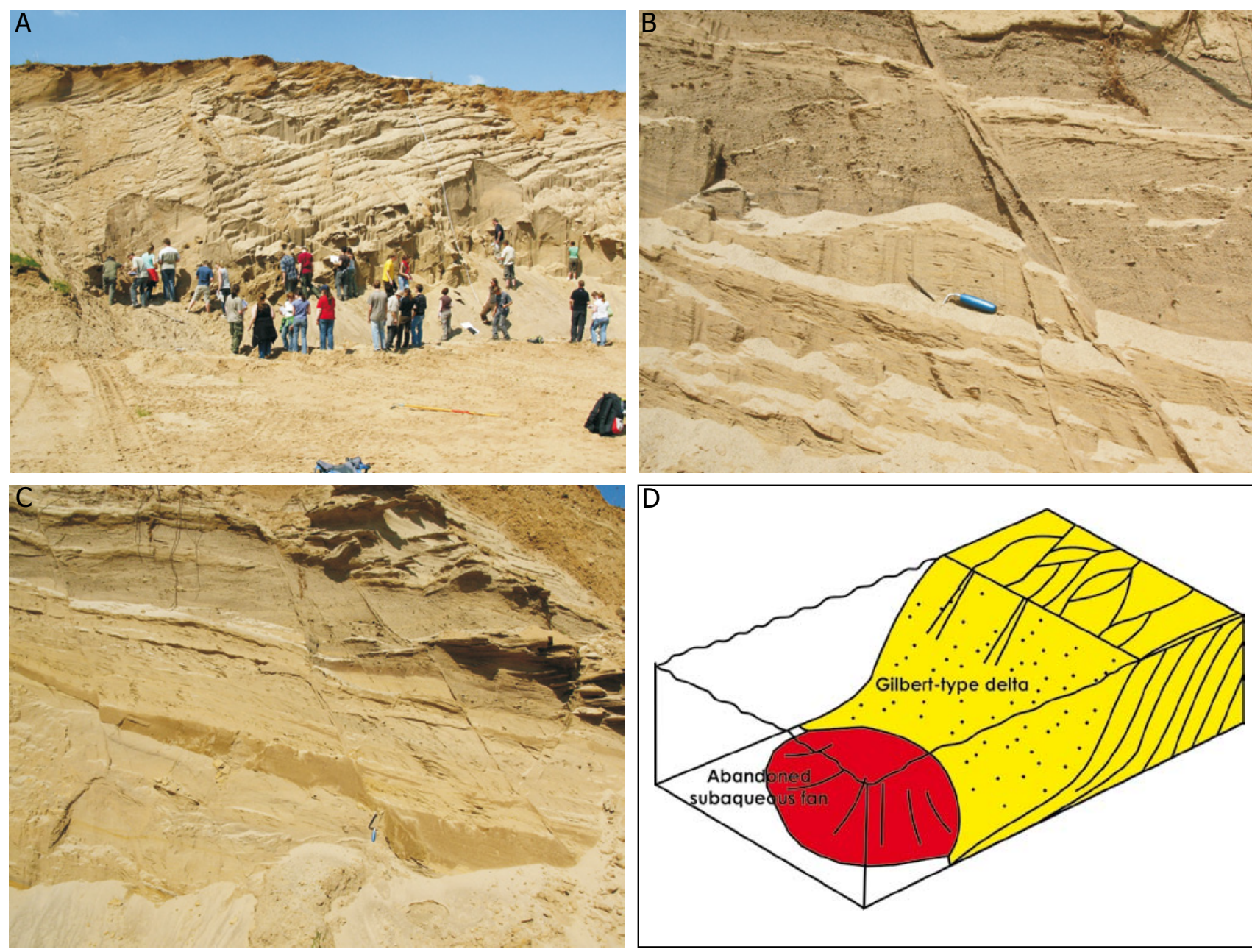

Fig. 13: Depositional architecture and sedimentary facies of the Freden subaqueous fan and delta complex. A) Steeply dipping delta foreset deposits, Ulrich pit. B) Close-up view of foreset beds, showing climbing-ripple cross-lamination and trough cross-stratification with normal deformation band faults, Ulrich pit. C) Climbing-ripple cross-laminated delta toeset deposits with normal deformation band faults, Ulrich pit. D) Depositional model of the Freden subaqueous fan and delta complex. Modified after WINSEMANN et al. (2007).

Abb. 13: Architektur und Sedimentfazies des Freden Komplexes. A) Steil einfallende Delta Foreset-Ablagerungen, Grube Ulrich. B) Nahaufnahme von Foreset-Ablagerungen mit Kletterrippeln, großdimensionierter, trogförmiger Schrägschichtung und Abschiebungen (,deformation band faults"), Grube Ulrich. C) Kletterrippeln in Delta Toeset-Ablagerungen mit Abschiebungen (,deformation band faults“), Grube Ulrich. D) Ablagerungsmodell für den FredenKomplex. Verändert nach WINSEMANN et al. (2007).

dicating a change in flow regime towards more tractional deposition from sustained turbulent flows. The mid-fan deposits are characterized by moderately dipping $\left(4^{\circ}-16^{\circ}\right)$ thin- to thick-bedded fine- to medium-grained massive, planar-parallel or ripple cross-laminated sand and silt beds, deposited from surge-like low-density turbidity currents.

Sediments exposed at the north-western Ulrich pit are mainly sandy and consist of planar and trough crossstratified pebbly sand and climbing-ripple cross-laminated sand, with a large-scale tangential geometry with dip angles from $2^{\circ}-30^{\circ}$ (Fig. 13A). The sedimentary succession is up to $25 \mathrm{~m}$ thick and palaeoflow directions are to the southeast and southwest. High- to low-angle bedding and the occurrence of migrating bedforms indicate an upper to lower delta slope environment (e.g., Clemmensen ¿ Houmark-Nielsen 1981, Fyfe 1990, Bornhold \& Prior 1990). The supply of meltwater-transported sediment to the delta slope was from steady seasonal flows. During higher energy conditions, 2-D and 3-D dunes formed, passing downslope into ripples (Fig. 13B and C). Scours filled with deformed strata or massive or diffusely graded sand and pebbly sand record rapid cut-and-fill processes on the lower delta slope probably associated with hydraulic jumps at a break in the slope gradient. During lower flow conditions, thick climbing-ripple cross-laminated sand beds accumulated also on higher parts of the delta slope (WinsEMANN et. al. 2007). The delta formation is attributed to an ice-front retreat, which became stabilized in front of the mountain ridge towards the east, corresponding with the shift in palaeoflow directions towards southerly and southwesterly directions (Fig. 12). Northwestward dipping climbing-ripple cross-laminated sand beds with palaeoflow directions towards the southeast probably have been deposited on the ice-proximal back-slope of an abandoned subaqueous fan (Fig. $13 \mathrm{C}$ and D). The strong progradation of delta foresets indicates a subsequent glacier stillstand and a period of high-sediment supply. The delta-foreset deposits are incised by a slope-cutting $\sim 25 \mathrm{~m}$ deep NW-SE trending U-shaped channel complex, filled with large-scale cross-stratified gravel, pebbly sand and ripple cross-laminated sand, silt and mud. This channel complex probably 


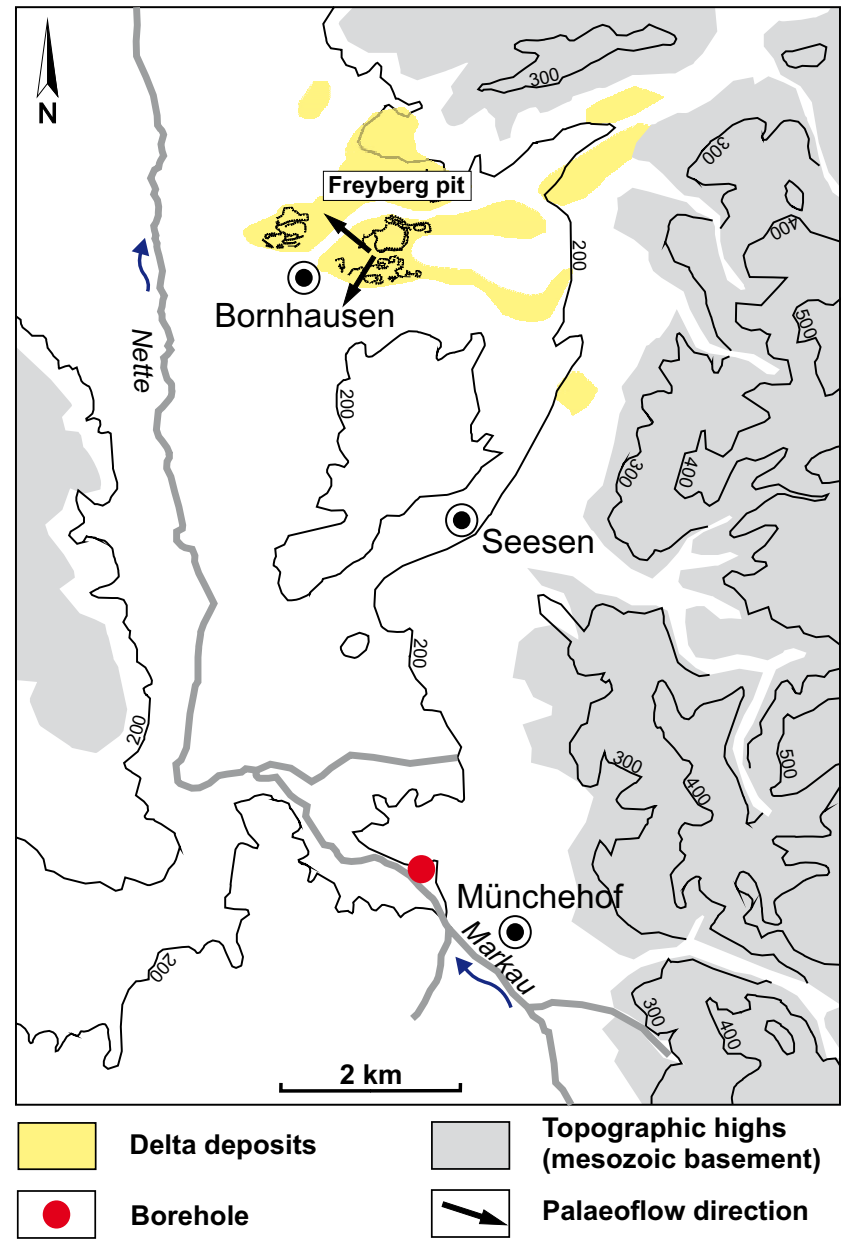

Fig. 14: Location of the Bornhausen delta. In the borehole north-west of Münchehof delta deposits of the River Markau have been drilled (HINZE 1976) indicating a lake level in the southern Nette Valley of at least $200 \mathrm{~m}$ a.s.l.

Abb. 14: Lage des Bornhausen Deltas. In der Bohrung nordwestlich von Münchehof wurden Delta-Ablagerungen der Markau erbohrt (HINZE 1976), die einen Seespiegel im südliche Nette-Tal von mindestens $200 \mathrm{~m} \ddot{u}$. NN anzeigen. formed in response to a lake-level fall, which led to the observed entrenchment and erosion of the upper foreset and topset beds since no subaerial, glaciofluvial or distributary delta-plain components have been recognized in the exposed sections.

\section{Internal deformation pattern}

The deformation of the Freden deposits includes both contractional and extensional structures. The older subaqueous fan complex shows thrust faults, recording glaciotectonic deformation of previously deposited ice-margin sediments. Within the stratigraphic younger delta complex, numerous extensional normal faults occur (Fig. 13B and C), which have previously been related to dead-ice melting in the subsurface (HARMS 1983, Feldmann 2002). New seismic and outcrop data however, indicate that these normal faults represent deformation band faults that are probably related to syn- or post-Saalian activity along basement faults (BRANDES et al. 2011). These basement faults are associated with a NE-SW trending salt-cored anticline in the subsurface. In large parts of the Ulrich pit, the deformation band faults trend NW-SE, fitting to the general basement structure. Dead-ice melting can be ruled out because of the lacking concentric fault pattern. Another possible explanation is gravity-induced delta tectonics. Fault activity might also be related to salt movements and enhanced crestal collapse or to a reactivation of the basement faults due to ice loading during glaciation.

\subsubsection{The Bornhausen delta}

The Bornhausen ice-margin deposits are located in the Nette Valley at an altitude of 160-180 m a.s.l. (Fig. 14) and form part of a larger complex of coarse-grained meltwater deposits, occurring over an altitude range of 140-215 m a.s.l. on the eastern margin of the Nette Valley (LÜTTIG 1962,

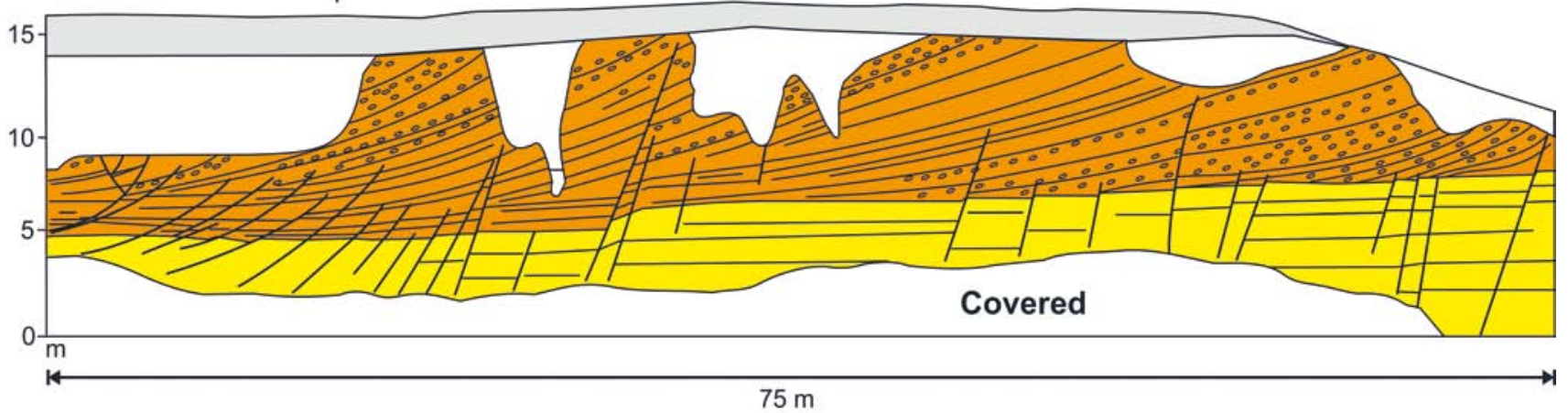

Fig. 15: Depositional architecture of the Bornhausen delta. The lower fine-grained delta toeset and bottomset deposits dip towards the south west. The overlying foreset beds steeply dip towards the north west, indicating the progradation of a new delta lobe. Note steeply north westward-dipping normal faults. Modified after FELDMANN (2002) and WINSEMANN et al. (2007).

Abb. 15: Architektur des Bornhausen Deltas. Die unteren feinkörnigen Delta Toeset- und Bottomset-Ablagerungen fallen nach Südwesten ein. Die überlagernden gröberen Foreset-Ablagerungen fallen steil nach Nordwesten ein und zeigen die Progradation eines neuen Delta-Lobus an. Die Delta-Ablagerungen werden von steilen, nach NW einfallenden Abschiebungen durchzogen. Verändert nach FELDMANN 2002 Und WINSEMANN et al. (2007). 
Hinze 1976, Bombien 1987, Feldmann 2002). These ice-marginal deposits overlie Neogene sediments and/or Middle Pleistocene till and glaciolacustrine sand and mud (GRUPE \& HAACK 1915, LütTig 1954, 1962, Uebersohn 1990). Palaeoflow directions indicate that meltwater flows from the north east were the main source of sediment (BOMBIEN 1987, Feldmann 2002, Winsemann et al. 2007). Clasts consist mainly of local material derived from the adjacent Mesozoic and Palaeozoic bedrock or resedimented fluvial material, previously deposited by the Neile River (BomBIEN 1987). Clasts with a Scandinavian/Baltic provenance constitute $\sim 10 \%$ of the total (UEBersohn 1990). Several previous workers have described the outcrops, assuming a subaerial glaciofluvial formation (e.g., GrUPE \& HAACK 1915, LÜtTig 1954, 1962, Thiem 1972, Hinze 1976, Heise 1996, UEBERSOHN 1990, FeldMANN \& GROETZNER 1998, ElbRACHT 2002, FELDMANN 2002).

Most pits have been refilled today but the Freyberg pit north of Bornhausen (Fig. 14) allowed a re-examination and detailed logging of sections (MEYER 2003, WinsEMANN et al. 2007). The measured section is exposed at an altitude of 161-177 $\mathrm{m}$ a.s.l., overlying up to $5.5 \mathrm{~m}$ thick glaciolacustrine mud and sand (LüTTIG 1962). The beds have a large-scale tangential geometry with dip angles from $10^{\circ}-28^{\circ}$. The lowermost section consists of $3 \mathrm{~m}$ thick, moderately $\left(10^{\circ}-14^{\circ}\right)$ southwest-dipping, very thin- to thick-bedded, massive, normally graded or climbing-ripple cross-laminated fineto coarse-grained sand. These deposits are disconformably overlain by $12 \mathrm{~m}$ thick, moderately- to steeply- $\left(12^{\circ}-28^{\circ}\right)$ northwestward-dipping, medium- to thick-bedded massive, normally or inversely graded or planar-parallel stratified pebbly sand, alternating with medium- to thick-bedded massive clast-supported gravel (Fig. 15).

Massive clast-supported gravel and pebbly sand with non-erosive basis or inverse distribution grading indicate deposition from cohesionless debris flows or sandy debrisflows, respectively, controlled mainly by the sediment's frictional strength, which would explain their low mobility and steep dip (Nemec et al. 1999). The intercalation of planar-parallel stratified pebbly sand indicate deposition from sustained turbulent density flows (KNELLER \& BRANNEY 1995, Plink-BjöRKLund \& RonNert 1999, Mulder \& AlEXANDER 2001) or thin diluted sandy debris flows, generated from cohensionless subaqueous debris flows by surface flow transformation (SoHN et al. 1997, SoHN 2000, Sohn, Choz \& Jo 2002). Evidence for the occurrence of flow-transformation is given by the observation that some gravel beds pass downslope into stratified pebbly sand. The finer-grained sandy material moved further downslope where it was deposited from both sustained and surgetype turbidity currents to form massive or climbing-ripple cross-laminated sand in the lower slope area. The observed disconformity in the lower section probably represents the onset of a new delta lobe progradation (Fig. 15). The sedimentary facies, high-angle tangential bedding and the absence of flow-till or ice-rafted debris points to a delta slope environment (Postma \& CRUickshank 1988, LøNNE 1995, Sohn et al. 1997, FAlK \& DorSey 1998). However, no subaerial, glaciofluvial or distributary delta-plain components have been recognized in the exposed section

\section{Internal deformation pattern}

Within the Bornhausen deposits, numerous normal faults occur, which have offsets of several $\mathrm{cm}$ to $\mathrm{dm}$ and dip steeply north westward. The formation of these faults has been related to mass-lost in the subsurface due to salt solution or deep-rooted tectonic crestal collapse on top of the Rhüden anticline (LütTig 1962, ÜBERSOHN 1990, FELdMANN 2002). Another possible driving mechanism for the formation of these normal faults is gravitational delta tectonics or differential compaction.

\section{Discussion}

\subsection{Depositional architecture of glaciolacustrine depositional systems}

The ice marginal depositional systems of the Weserbergland and Leinebergland are characterized by coarse-grained deltas and subaqueous fans deposited from high-energy meltwater flows. The observed facies associations are consistent with previous descriptions of coarse-grained delta deposits (e.g., Clemmensen \& Houmark-Nielsen 1981, Postma \& CRUickshank 1988, Bornholt \& Prior 1990, Nemec 1990, Lønne 1995, SoHn et al. 1997, Nemec et al. 1999) and glacigenic subaqueous fan deposits (e.g., CHEEL ひ Rust 1982, Eyles \& Clark 1988, Sharpe 1988, Sharpe $\mho$ Cowan 1990, LøNne 1995, 2001, Plink-BJÖRkLund \& RoNNERT 1999, Russell $\&$ ARnott 2003, Bennett, Huddart $\approx$ Thomas 2007, Russell, Sharpe \& Bajc 2007). The sedimentary facies, morphology, and extent of ice-marginal deposits indicate deposition into proglacial lakes at the margin of a temperate lobate, grounded ice sheet (e.g., Ashley, Boothroyed \& BorNs 1991). The groundling line of temperate glaciers is the one where the largest volume of sediment is deposited and large quantities of glaciofluvial bedload and suspended load can be transported and deposited by jets (PowELl \& DomACK 1995). In glaciolacustrine environments, sediment-laden meltwater is generally denser than the surrounding lake water, and will tend to produce underflows (Fig. 16 A). Deposition on grounding line subaqueous fans is therefore likely to be dominated by gravity flows, with comparatively minor inputs from high-level suspended sediment (BENN \& EvANS 1998). If the ice terminus remains stable for a long period of time, a grounding line fan may aggrade to lake level and form an ice-contact/ glaciofluvial delta (Powell 1990, LøNnE, 1995).

The position of ice marginal fans and deltas in the study area was controlled by the combination of bedrock topography and water depth. Correspondingly depositional processes and the resulting facies architecture of depositional systems are highly variable. The delta complexes reflect a relatively stable position of the ice-margin in front of mountain ridges or major basement highs (Fig. 16 B). Subaqueous fans commonly reflect more unstable icefronts of smaller ice-lobes that advanced into the lake basins and were subject to periodic calving and short-term oscillations (e.g., Fowler 1987, Fyfe 1990, Powell 1990, POWELl \& DOMACK 1995).

The ice-marginal deposits of glacial Lake Weser and glacial Lake Leine mainly record the sedimentation dur- 

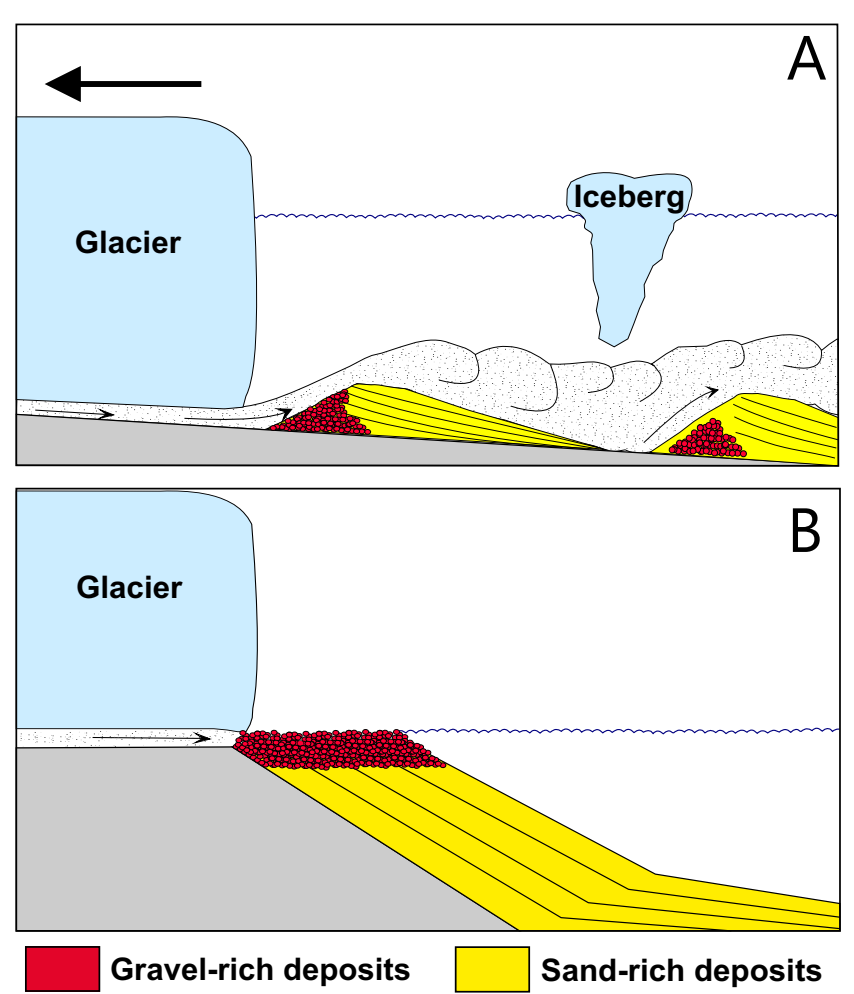

Fig. 16: Schematic model of glaciolacustrine ice-margin deposits. A) Depositional architecture of subaqueous ice-contact fans during ice-margin retreat. B) Depositional architecture of a glaciofluvial Gilbert-type delta. Modified after POWELL (1990) and LøNNE (1995).

Abb. 16: Schematisches Ablagerungsmodell für glazilakustrine EisrandSysteme. A) Schematisches Modell eines subaquatischen Eiskontaktfächers während eines Eisrückzugs. B) Schematisches Modell eines glazifluviatilen Gilbert-Deltas. Verändert nach LøNNE (1995) and POWELL \& DOMACK (1995).

ing ice-sheet retreat. This is most likely because proglacial deposits are commonly overridden and incorporated into the base of the ice during ice advance (AsHLEY 1995). After a phase of maximum ice-advance, accompanied by the deposition of ice-contact subaqueous fan deposits and deformation of fan deposits, a rapid back-stepping of fan bodies towards up-slope positions occurred. Individual fan bodies commonly have a coarse-grained core of flat-lying to steeply dipping gravel, overlain by fining-upward packages of gravel, sand and mud (Fig. 16A). During ice-margin retreat, often rhythmically laminated fine-grained sediments rich in ice-rafted debris were deposited on both the ice-distal and ice-proximal slopes of the abandoned fans. Climbing-ripple cross-laminated sand may onlap coarsegrained upper fan gravel and in some cases overtop the older fan deposits (Fig. 11).

Ice-margin retreat was probably caused by an overall lake level rise. Bedrock highs acted as pinning points for the retreating ice lobes and after the re-establishment of the subglacial drainage systems, ice-marginal sediment accumulated from restricted point sources, giving rise to small isolated subaqueous fans. Smaller conduits are more unstable and have smaller effluxes, which more easily mix with lake water, so constraining the distance of sediment dispersal (Fyfe 1990, SHARPE \& COWAN 1990). The lack of subaerial topset facies demonstrates that the retreat was fast and fans did not reach the contemporary water-level (LøNNE 1995).
The large size of the northernmost Porta fan system (fan III, Fig. 5 and Fig. 6) is attributed to the position in front of the Porta Westfalica pass, where a stable meltwater tunnel facilitated the construction of a larger subaqueous fan. The dimension of jet-efflux deposits is much larger than that of previously described examples from the Laurentide Ice Sheet (e.g., Gorrell \& SHaw 1991, Russell \& ARNOTT 2003) and the frequent occurrence of tractive structures in gravelly and sandy fan deposits indicates sustained and high-energy flows associated with high discharges (Powell 1990, LønNe 1995, Cutler, Colgan \& Mickelson 2002).

When the retreating ice lobes stabilized in front of mountain ridges, subaqueous ice-contact fans could buildup to the lake-level and evolve into ice-contact deltas/glaciofluvial deltas as observed in the Freden subaqueous fan and delta complex (Fig. 12 and Fig. 13D). In the Weser Lake, strong lake-level falls led to a widespread truncation of subaqueous fan deposits, which partly became overlain by delta deposits (Fig. 7).

\subsection{Deformation structures}

The observed deformation structures within the ice-marginal deposits mainly consist of normal faults and deformation band faults. The occurrence of normal faults in icemarginal deposits is commonly related to mass-loss due to dead ice-melting (e.g., SElsing 1981, Harms 1983, Prange 1995, Juschus 2003). However, re-examination of tectonic deformation structures by BRANDES, PolOM \& WinsEMANN (2011) and BrAndes et al. (2011) indicate that this extensional deformation was most probably caused by other mechanisms such as gravity induced delta tectonics, crestal collapse above salt domes and a reactivation of basement faults due to ice and water loading/unloading.

The strong influence of ice-loading on the regional seismicity was shown by several authors (e.g., DeHLs et al. 2000, FJeldskaAr et al. 2000, Stewart, SAuber \& Rose 2000) and a reactivation of normal faults caused by lake formation was documented for the Wasatch Fault in the western U.S. (Hetzel \& HAMPEL, 2005). In our study area the lithosphere was effected by i) the growth and decay of the Drenthe ice-sheet and associated proglacial lakes and ii) local sediment loading by thick ice-marginal deposits. It is very likely that the basement coupled deformation in the study area was caused by the advance of the Drenthe ice sheet (Brandes, Polom \& Winsemann 2011). The interplay of ice sheet and tectonic structures in northern Germany was previously discussed by ReICHERTER, KAISER \& STACKEBRANDT (2005) and described by AdAms (1989), Liszowski (1993) and Stewart, SAuber \& Rose (2000) from Canada, Poland and Scandinavia, respectively. The flexure of the lithosphere due to glacial loading created a compressive stress at the front of the ice sheet and the fore-bulge area was characterized by uplift and extension as described in the model of Stewart, SAuber \& Rose (2000). The advance of the ice-sheet induced a transfer of the stressfront through the upper lithosphere and pre-existing basement faults were probably reactivated due to the varying stress conditions. The Triassic-Jurassic normal faults trend WNW-ESE parallel to the Saalian ice-margin (Fig. 9). They 
were in an ideal position for a reactivation due to the extensional stress field in the foreland of the glacier because the orientation of the glacier induced stress field matches the orientation of the palaeo-stress field. The growth of the ice-marginal deltas and subaqueous fans created a local load that might have enhanced the reactivation of normal faults in the basement. The water pressure could have reduced the friction along the faults and supported the slip process. SiRоско et al. $(2002,2008)$ described young halokinetic movements in northern Germany, related to salt diapirs. Salt structures in the study area are present below the Freden and Bornhausen ice-margin deposits. In this case, salt tectonics may have played an important role. Though a reactivation of pre-existing basement faults and salt structures due to loading and related effects is very likely, a neotectonic component cannot be ruled out.

\subsection{Influence of Saalian proglacial lakes on ice sheet dynamics}

The formation of proglacial lakes may exert an important influence on ice sheets. Calving speed in fresh water scales linearly with water depth and exponentially with ice temperature (Warren, Greene \& Glasser 1995). Progressive deepening of lakes therefore, may lead to an increased removal of ice through calving and an increase of subglacial water pressure proximal to the ice (CUTLER et al. 2001, WinsBorrow et al. 2010). Compared to adjacent areas of ice sheet terminating on dry land, this would have the effect of reducing the basal shear stress and an increase in ice velocity up-ice from the lake (STOKEs $\&$ ClARKE 2004).

We assume that the formation and catastrophic drainage of deep proglacial lakes in front of the Drenthe ice sheet considerably influenced the ice-sheet stability and may have initiated the Hondsrug ice stream. The Drenthe glaciation in the study area is characterized by three different ice-advances (e.g., VAN DEN BERG \& BEETs 1987, KLostermann 1992, Skupin, SpeEtzen \& Zandstra 1993, 2003). The first ice advance had a southerly to slightly southeasterly direction (SKupin, SpeETZEN \& ZANDSTRA 1993, EHLERs et al. 2004) and blocked the northward drainage pathway of the Weser River and Leine River, leading to the incipient formation of proglacial lakes in front of the Drenthe ice-sheet. During this ice advance, the Leine Lake basin was completely blocked whereas the Weser Lake could probably still drain southwestward along the Teutoburger Wald Mountains (e.g., KLostermann 1992). The maximum ice extent in the Upper Weser and Leine Valley was reached and the lower portions of the Porta, Coppenbrügge, and Freden complex were probably deposited.

From the Netherlands and northwestern Germany a second southwestward-directed ice advance is recorded (VAN Den Berg \& Beets 1987, Skupin, Speetzen \& Zandstra 1993, 2003, EhLERs et. al. 2004). During this ice advance, an ice lobe intruded into the Münsterland Embayment and the valley between the Teutoburger Wald Mountains and Wiehengebirge Mountains, leading to the successive closure of lake overspill channels in the Teutoburger Wald Moun- tains (Thome 1983, Klostermann 1992, Skupin, Speetzen of ZANDSTRA 1993, 2003). The closure of these overspill channels caused the observed long-term transgression of the Weser Lake. As a consequence the ice lobes within the northernmost Weser Valley rapidly collapsed and a new ice margin became stabilized in front of the Wesergebirge Mountains (WINSEMANN et. al. 2007). At the western lake margin, ice-marginal deposits (Markendorf delta, Ravensberger Kiesssandzug) became deformed and overridden (Skupin, SpeEtzen \& Zandstra 2003).

At the easternmost Münsterland Embayment, a proglacial lake formed in front of the Münsterland ice lobe (Тноме 1998, Herget 1998). This lake is referred to as "glacial Lake Paderborn" (Thome 1998) or "glacial Lake Münsterland” (Meinsen et al., in press), respectively. During highstand, the lake had a maximal lake level of $\sim 350 \mathrm{~m}$ a.s.l. (Herget 1998) and probably a maximum depth of up to $\sim 170 \mathrm{~m}$ (Meinsen et al. in press). The lake drained southwestwards into the Möhne and Ruhr valley through outlet channels, located at the southwestern lake margin (Тноме 1983, 1998, Herget 1998).

The progressive deepening of lakes in the Münsterland Embayment and Upper Weser Valley probably led to an increased removal of ice through calving, a rapid retreat of the western ice-lobes and opening of the $135 \mathrm{~m}$ a.s.l. and $95 \mathrm{~m}$ a.s.l. overspill channels in the Teutoburger Wald Mountains. During the subsequent Weser Lake outburst floods, 110 $\mathrm{km}^{3}$ of water was released into the Münsterland Embayment and the lake level of the Weser Lake dropped by as much as $100 \mathrm{~m}$ (Fig. 4). These two outburst floods must have led to an increase in the ice temperature due to frictional heating and enhanced melting and rapid destabilization of the Münsterland ice lobe (Meinsen et al. in press). Subsequently, an ice re-advance occurred, leading to the renewed closure of the $95 \mathrm{~m}$ a.s.l. overspill channel and a related lake-level rise of glacial Lake Weser (Fig. 4). This ice-advance is related to the Hondsrug ice stream (VAN DEN BERG \& BEETs 1987, PASSCHIER et al. 2010), which is the last ice advance recorded from the Münsterland Embayment (SKupin, SPEETZEN \& ZANDSTRA 1993). We speculate that the Hondsrug ice stream may have been enhanced or even triggered by the combination of glacial lake formation in the Münsterland Embayment and outburst floods of glacial Lake Weser. The associated removal of ice may have led to a rapid draw-down of ice, triggering fast ice flow (STOKES \& CLARK 2004, WINSBORRow et al. 2010).

After the drainage of glacial Lake Weser and glacial Lake Münsterland the Hondsrug ice stream advanced into the Münsterland Embayment, probably considerably thinning the ice sheet profile in this region. The splayed, lobate pattern of the Hondsrug ice stream (VAN DEN BERG \& BEETS 1987, Skupin, Speetzen \& Zandstra 1993) indicates that it probably terminated on dry land or discharged into very shallow water. STOKES \& CLARK (2004) pointed out that once achieved, the calving processes and losses might play a secondary role in the functioning of an ice stream and once rapid basal sliding is established thermomechanical feedback mechanism may sustain fast ice flow. Subsequently the thinned Drenthe ice sheet deglaciated rapidly (vaN DEN Berg \& BeEts 1987, PAsschier et al. 2010). 


\subsection{Implications for the position of the Elsterian ice- margin and associated proglacial lakes}

The position of the Elsterian ice-margin in the study area is unclear and several reconstructions of the Elsterian ice-margin have assumed a glacial advance into the Upper Weser and Upper Leine Valley (e.g., LiEDTKE 1981, JoRDAN \& Schwartau 1993, Klostermann 1995, Thome 1998, FELDMANN 2002, EhLERs et. al. 2004).

The assumption of a farther southward reaching Elsterian ice-margin is based on

1. the occurrence of scattered erratic clasts beyond the Saalian ice-margin (e.g., WALDECK 1975, JoRDAN 1994)

2. the occurrence of reworked erratic clasts in Middle Pleistocene fluvial deposits (e.g., RoHDE \& THIEM 1998). Based on this study, it seems more likely that scattered erratic clasts beyond the Saalian ice-margin represent icerafted debris dumped from icebergs rather than being relics of reworked Elsterian deposits. Middle Pleistocene fluvial deposits with reworked erratic clasts might represent Saalian deposits that formed in response to temporal glacial lake formation and rapid lake drainage. We therefore assume that all ice-marginal sediments of the Weserbergland- and Leinebergland have been deposited into the Saalian proglacial lakes. A Saalian age of these ice-marginal deposits is also assumed in new geological maps (1: 50 000) of the LBEG.

Тноме (1998) proposed the existence of even larger glacial lakes in the Upper Weser and Leine Valley during the Elsterian glaciation. He argued that glacial Lake Weser stood at a level of $300 \mathrm{~m}$ a.s.l., controlled by the altitudes of potential outlet channels. Since there is no evidence that the Elsterian ice margin did reach farther south westward than the Saalian Drenthe ice sheet, it is not very likely that a large lake was dammed in the Upper Weser Valley because the water would have probably drained along the Teutoburger Wald Mountains. The examination of more than 2000 borehole logs in the Upper Weser Valley gave no evidence for the existence of older pre-Saalian glacial lake sediments. However, fluvial erosion might have led to a complete removal of older deposits.

The existence of a larger Elsterian proglacial lake in the Upper Leine Valley is more likely because the Leine Valley has less potential lake outlets and the thick accumulation of fine-grained lake deposits may also contain older Elsterian deposits (e.g., JoRDAN 1984, 1986).

\section{Conclusions}

The re-examination of Middle Pleistocene ice-marginal deposits in the Weser- and Leinebergland reveal that these deposits consists of ice-contact deltas and subaqueous fans deposited from high-energy meltwater flows into large and deep proglacial lakes.

- Based on the new interpretation of ice-marginal depositional systems, lake-levels of approximately $200 \mathrm{~m}$ a.s.l. must be considered for both glacial Lake Weser and glacial Lake Leine during the Saalian Drenthe glaciation.

- The geometry and sedimentary facies of subaqueous fan and delta deposits indicate deposition into proglacial lakes at the margin of the retreating ice sheet. The position of ice marginal fans and deltas was controlled by the combination of bedrock topography and water depth. During ice-lobe retreat, bedrock highs served as pinning points whereas a flatbottom topography caused a more rapid ice wastage because the ice terminated in deeper water and the calving rate may have exceeded the ice flux, resulting in rapid retreat.

- Subaqueous fans formed where glaciofluvial detritus were carried to the lake via tunnels near or at the base of an ice cliff, commonly associated with an unstable ice-front. Individual fan bodies have a coarse-grained proximal core of flat-lying to steeply-dipping gravel, overlain by sandrich mid- to outer-fan deposits. During glacier retreat, finegrained sediments were deposited on the ice-distal and iceproximal slopes of the abandoned fans. During lake-level fall, the subaqueous fan systems emerged and were partly overlain by delta deposits.

- The formation of delta complexes reflects a relatively stable position of the ice-margin in front of mountain ridges or major basement highs that acted as pinning points. The sedimentary facies and depositional architecture of ice-marginal deltas resemble those of non-glacial Gilberttype deltas, except for the deposition of glacial debris.

- The observed deformation structures within the icemarginal deposits comprise both contractional and extensional features. Contractional structures are related to glaciotectonic processes. However, most commonly normal faults and deformation band faults are developed. Different driving mechanisms caused this extensional deformation including gravity induced delta tectonics, crestal collapse above salt domes and a reactivation of basement faults due to ice and water loading and unloading. In some cases, a neotectonic component cannot be ruled out. Dead-ice melting, however, did not play a major role.

- We hypothesise that the formation of deep proglacial lakes in the study area considerably influenced the stability of the southern Drenthe ice sheet and prevented a farther southward ice advance into the Upper Weser and Leine Valley by an increased removal of ice through calving.

- We speculate that the Hondsrug ice stream may have been enhanced or even triggered by the combination of glacial lake formation in the Münsterland Embayment and outburst floods of glacial Lake Weser. The associated removal of ice may have led to a rapid draw-down of ice, triggering fast ice flow and deglaciation.

- Based on our valley-fill analysis, it seems unlikely that the Elsterian ice sheet reached farther south than the Saalian Drenthe ice sheet in the study area.

\section{Acknowledgement}

Financial support by the MWK Niedersachsen (11.2-7620217-7/08) is gratefully acknowledged. We thank reviewers $\mathrm{O}$. Juschus and W. Stackebrandt for helpful comments, which helped to improve the manuscript. S. Cramm, S. Grüneberg, W. Rode and D. Vogel (LIAG) carried out the seismic survey and J. Meinsen and D. Steinmetz helped with artwork. Special thanks go to the Geological Survey of Lower Saxony (LBEG) for providing the borehole data and the owners of the sand and gravel pits for the permission to work on their properties. This work also benefited from the discussion with many colleagues; in particular we would like to thank 
B. Deters, J. Elbracht, the late J.-P. Grötzner, F.-J. Harms, H. Jordan, B. Rakowski, H. Röhm, P. Rohde, K. Skupin, E. Speetzen, D. Tanner and P. Wellmann for discussion and providing unpublished data. Many thanks are also due to J. Buscher for improving the English.

\section{References}

ADAms, J. (1989): Postglacial faulting in eastern Canada: nature, origin and seismic hazard implications. - Tectonophysics, 163: 323-331.

Ashley, G. M. (1995): Glaciolacustrine Environments. - In: Menzies, J. (ed.): Modern Glacial Environments: 417-444; Oxford (Butterworth-Heinemann).

Ashley, G.M., Boothroyed, J.C. \& Borns, H.W., JR. (1991): Sedimentology of late Pleistocene (Laurentide) deglacial-phase deposits, eastern Maine; an example of a temperate marine grounded ice sheet margin. - In: Ashley J.B. \& Ashley G.M. (eds.): Glacial Marine Sedimentation, Paleoclimatic Significance. - Geological Society of America Special Paper, 261: 107-125.

Aтtıg, K. (1965): Das Quartär südöstlich der Porta Westfalica unter besonderer Berücksichtigung der glaziofluviatilen Sedimente. - 43 S., unpublished diploma thesis; University of Braunschweig.

Benn, D.I. \& Evans, D.J.A. (1998): Glaciers \& Glaciation. - 734 S.; London (Arnold).

Bennett, M.R., Huddart D. \& Thomas, G.S.P. (2007): The Newbigging esker system, Lanarkshire, southern Scotland: a model for composite tunnel, subaqueous fan and supraglacial esker sedimentation. - In: Hambrey, M., Christoffersen, P., Glasser N \& Hubbard, B. (eds.): Glacial Processes and Products. - IAS Specical Publications, 39: 177-202.

Bilotті, F. \& Shaw, J.H. (2005): Deep-water Niger delta fold and thrust belt modelled as a critical -taper wedge: the influence of elevated basal fluid pressure on structural styles. AAPG Bulletin, 89: 1475-1491.

BLum, M.D. \& TöRnQvist, T.E. (2000): Fluvial responses to climate and sealevel change: a review and look forward. - Sedimentology, 47 (Suppl. 1): $2-48$.

BombIEN, H. (1987): Geologisch-petrographische Untersuchungen zur quartären (früh-Saale-zeitlichen) Flußgeschichte im nödlichen Harzvorland. - Mitteilungen aus dem Geologischen Institut der Universität Hannover, 26: 1-131.

Bornhold, B.D. \& PRIOR, D.B. (1990): Morphology and sedimentary processes on the subaqueous Noeick River delta, British Columbia, Canada. - In: Colella, A. \& Prior, B.D. (eds.): Coarse-Grained Deltas. - IAS Specical Publications, 10: 169-181.

Brandes, C., Polom, U. \& Winsemann, J. (2011): Reactivation of basement faults: interplay of ice-advance, glacial lake formation and sediment loading. - Basin Research, 23: 53-64. Doi: 10.1111/j.1365 $-2117.2010 .00465 . x$.

Brandes, C., Tanner, D., Polom, U. \& Winsemann, J. (2011): Deformation bands in Pleistocene sediments related to basement tectonics. - Geophysical Research Abstracts, EGU Meeting 2011, Wien.

Busschers, F.S., Van Balen, R.T., Cohen, K.M., Kasse, C., Weerts, H.J.T., Wallinga, J. \& Bunnik, F.P.M. (2008): Response of the Rhine -Meuse fluvial system to Saalian ice-sheet dynamics. - Boreas, 37: 377-398.

Carling, P.A., Kirkbride, A.D., Parnachov, S., Borodavko, P.S. \& BergER, G.W. (2002): Late Quaternary catastrophic flooding in the Altai Mountains of south-central Siberia: a synoptic overview and an introduction to flood deposit sedimentology. - In: Martini, P.I., Baker, V.R. \& Garzon, G. (eds.): Flood and Megaflood Processes and Deposits: Recent and Ancient Examples. - IAS Specical Publications, 32: 17-35.

Caspers, G., Jordan, H., Merkt, J., Meyer, K.-D., Müller, H. ひ Streif, H. (1995): III. Niedersachsen. - In: BENDA, L. (ed.): Das Quartär Deutschlands: 23-58; Berlin (Gebr. Bornträger).

Cheel, R.J. \& Rust, B.R. (1982): Coarse grained facies of glaciomarine deposits near Ottawa, Canada. - In: DAvidson-Arnott, R. Nickling W. \& FAHEY B.D. (eds.): Research in Glaciofluvial and Glaciolacustrine Systems: 279-295. Norwich (Geo Books).

Clark, J.D. \& Pickering, K.T. (1996): Architectural elements and growth pattern of submarine channels: application to hydrocarbon exploration. - AAPG Bulletin, 80: 194-221.

Clemmensen, L.B. \& Houmark-Nielsen, M. (1981): Sedimentary features of a Weichselian glaciolacustrine delta. - Boreas, 10: 229-245.

Colman, S.M., Clark, J.A., Clayton, L., Hansel, A.K. \& Larsen, C.E. (1994): Deglaciation, lake levels, and meltwater discharge in the Lake Michigan Basin. - Quaternary Science Reviews, 13: 879-890.
Cutler, P.M., Mickelson, D.M., Colgan, P.M., MacAyeal, D.R. ¿ ParIZEK, B.R. (2001): Influence of the Great Lakes on the dynamics of the southern Laurentide ice sheet: Numerical experiments. - Geology, 29: 109-1042.

Cutler, P.M., Colgan, P.M. \& Mickelson, D.M. (2002): Sedimentologic evidence for outburst floods from the Laurentide Ice Sheet margin in Wisconsin, USA: implications for tunnel-channel formation. - Quaternary international, 90: 23-40

Dehls, J.F., Olesen, O., Olsen, L. \& Blikra, L.H. (2000): Neotectonic faulting in northern Norway; the Stuoragurra and Nordmannvikdalen postglacial faults. - Quaternary Science Reviews, 19: 1447-1460.

Deters, H.-B. (1999): Internbau und Genese von zwei pleistozänen KiesSand-Vorkommen östlich von Hameln (Afferde, Coppenbrügge) im Niedersächsischen Bergland. - 100 S.; unpublished diploma thesis; University of Hannover.

Deutloff, O., Kühn-Velten, H., Michel, G., \& Skupin, K. (1982): Erläuterungen zu Blatt C3918 Minden, Geologische Karte von Nordrhein -Westfalen 1: 100 000. - 80 S.; Krefeld.

Driever, E. (1921): Die Entwicklung des Längstales Porta-Osnabrück. Jahresberichte des naturwissenschaftlichen Vereins Osnabrück, 18: $1-88$.

Ehlers, J., Eissmann, L., Lippstreu, L., Stephan, H.-J. \& WANSA, S. (2004) Pleistocene glaciations of North Germany. - In: Ehlers, J., GibBard, P. (eds.): Quaternary Glaciations. Extent and Chronology Part I, Europe: 135-146; Amsterdam (Elsevier).

EISSMANN, L. (1997): Das quartäre Eiszeitalter in Sachsen und Nordostthüringen. - Altenburger Naturwissenschaftliche Forschung, 8: 1-98.

EISSMANN, L. (2002): Quaternary geology of eastern Germany (Saxony, Saxon -Anhalt, South Brandenburg, Thüringia), type area of Elsterian and Saalian Stages in Europe. - Quaternary Science Reviews, 21: $1275-1346$

ELBRACHT, J. (2002): Karbonatische Zementation pleistozäner Lockersedimente in NW-Deutschland. - 111 S.; unpublished doctoral thesis, University of Hannover.

EYLES, N. \& CLARK, B.M. (1988): Storm-influenced deltas and ice scouring in a late Pleistocene glacial lake. - GSA Bulletin, 100: 793-809.

FALK, P.D. \& DoRSEY, R.J. (1998): Rapid development of gravely high -density turbidity currents in marine Gilbert-type fan deltas, Loreto basin, Baja California Sur, Mexico. - Sedimentology, 45: 331-349.

FARRENSCHON, J. (1995): Erläuterungen zu Blatt 4020 Blomberg, Geologische Karte von Nordrhein-Westfalen 1: 25 000. - 155 S.; Krefeld.

FeldmanN, L. (2002): Das Quartär zwischen Harz und Allertal mit einem Beitrag zur Landschaftsgeschichte im Tertiär. - Clausthaler Geowissenschaften, 1: 1-149.

Feldmann, L. \& J.-P. Groetzner (1998): Leinebergland und nördliches Harzvorland. - In: Feldmann, L. \& Meyer, K.D. (eds.): Quartär in Niedersachsen. Exkursionsführer zur Jubiläums-Hauptversammlung der Deutschen Quartärvereinigung in Hannover, Exkursion B: 37-88; Hannover.

FjeldskaAr, W., Lindholm, C. Dehls, J.F. \& FJeldskaAr, I. (2000): Postglacial uplift, neotectonics and seismicity in Fennoscandia. - Quaternary Science Reviews, 19: 1413-1422.

FowlER, A.C. (1987): Sliding with cavity formation. - Journal of Glaciology, 33: 255-267.

Fyfe, G. (1990): The effects of water depth on ice-proximal glaciolacustrine sedimentation: Salpausselkä I, southern Finland. - Boreas, 19: $147-164$.

Gorell, G. \& Shaw, J. (1991): Deposition in an esker, bead and fan complex, Lanark, Ontario, Canada. - Sedimentary Geology, 72: 285-314.

Groetzner, J.-P. (1995): Central Upland Traverse, 9th day. - In: Schirmer W. (ed.): Quaternary Field Trips in Central Europe: 588-590; 14th International INQUA Congress Berlin; München (Dr. Friedrich Pfeil).

GrupE, O. \& HAACK, W. (1915): Erläuterungen zu Blatt 4026 Lamspringe, Geologische Karte von Preußen und benachbarten Bundesstaaten 1: 25 000. - 80 S.; Berlin.

Grupe, O. (1926): Tal- und Terrassenbildung im Gebiete der Werra-FuldaWeser und Soergels „Gliederung und absolute Zeitrechnung des Erdzeitalters“. - Geologische Rundschau, 17: 161-196.

Grupe, O. (1930): Die Kamesbildungen des Weserberglandes. - Jahrbuch der Preußischen Geologischen Landes-Anstalt, 51: 350-370.

Grupe, O., Koert, W. \& Stach, E. (1933): Erläuterungen zu Blatt 3719 Minden, geologischen Karte von Preussen und benachbarter deutscher Länder 1: 25 000. - 67 S., Berlin.

Harms, F. -J. (1983): Zur Geologie saalezeitlicher Sedimente am Rande des Leinetals zwischen Imsen und Freden. - Beiträge zur Naturkunde Niedersachsens, 36, Jahrgang 2: 53-69. 
Harms, F.-J. (1984): Erläuterungen zu Blatt Nr. 4025 Freden, Geologische Karte von Niedersachsen 1: 25 000. - 168 S.; Hannover.

HeIse, K. (1996): Petrographische Zusammensetzung und Alter von Kleinvorkommen glaziärer Sedimente im NW Harzvorland. - 52 S.; unpublished diploma thesis; University of Hannover.

HergEt, J. (1998): Temporäre Entwässerungsbahnen am Südrand der Westfälischen Tieflandsbucht - ein Szenario. - In: GlatthAAR, D. \& HerGET, J. (eds.): Physische Geographie und Landeskunde - Festschrift für Herbert Liedtke. - Bochumer Geographische Arbeiten Sonderreihe, 13: 23-30.

HerrmanN, R. (1958): Eisrandablagerungen und Fließerden am Nordrand des Leineberglandes. - Geologisches Jahrbuch, 76: 309-320.

Hesemann J. (1975): Geologie Nordrhein-Westfalens. - 416 S.; Paderborn (Ferdinand Schöningh).

Hetzel, R. \& HAmpel, A. (2005): Slip rate variations on normal faults during glacial-interglacial changes in surface loads. - Nature, 435: 81-84.

Hinze, C. (1976): Erläuterungen zu Blatt Seesen Nr. 4127, Geologische Karte von Niedersachsen 1: 25 000 - 161 S.; Hannover.

Hornung, J.J., Asprion, U. \& Winsemann, J. (2007): Jet-efflux deposits of a subaqueous ice-contact fan, glacial Lake Rinteln, northwestern Germany. - Sedimentary Geology, 193: 167-192.

JAREK, M. (1999): Kartierung und Faziesanalyse der Emme: Ein drenthezeitlicher Deltakomplex am Südhang des Wesergebirges. - $66 \mathrm{~S}$.; unpublished diploma thesis; University of Hannover.

JoHnsEN, T. F. \& BRENNAND, T.A. (2006): The environment in and around ice-dammed lakes in the moderately high relief setting of the southern Canadian Cordillera. - Boreas, 35: 106-125.

JORDAN, H. (1984): Erläuterungen zu Blatt Nr. 4325 Nörten-Hardenberg, Geologische Karte von Niedersachsen 1: 25 000. - 146 S.; Hannover.

JoRDAN, H. (1986): Erläuterungen zu Blatt Nr. 4225 Northeim West, Geologische Karte von Niedersachsen 1: 25 000. - 144 S.; Hannover.

JoRDAN, H. (1989): Geologische Wanderkarte Leinebergland 1: 100000. Hannover.

JoRDAN, H. (1993): Erläuterungen zu Blatt Nr. 4125 Einbeck, Geologische Karte von Niedersachsen 1: 25 000 - 107 S.; Hannover.

JoRDAn, H. (1994): Erläuterungen zu Blatt Nr. 4024 Alfeld, Geologische Karte von Niedersachen 1: 25 000. - 126 S.; Hannover.

JoRDAN H. \& SCHWARTAU, W. (1993): Das Lößprofil von Ahlshausen und weitere tiefe Quartäraufschlüsse entlang der Bundesbahn-Neubaustrecke bei Northeim, Südniedersachen. - Eiszeitalter und Gegenwart, 43: $110-122$.

JunGE, F.W. (1998): Die Bändertone Mitteldeutschlands und angrenzender Gebiete. - Altenburger Naturwissenschaftliche Forschung, 9: 1-210.

Juschus, O. (2003): Das Jungmoränenland südlich von Berlin - Untersuchungen zur jungquartären Landschaftsentwicklung zwischen Unterspreewald und Nuthe. Berliner Geographische Arbeiten, 95: 1-152.

KaltwANG, J. (1992): Die pleistozäne Vereisungsgrenze im südlichen Niedersachsen und im östlichen Westfalen. - Mitteilungen aus dem Geologischen Institut der Universität Hannover, 33: 1-161.

KlostermanN, J. (1992): Das Quartär der Niederrheinischen Bucht - Ablagerungen der letzten Eiszeit am Niederrhein. - 200 S.; Krefeld (Geologisches Landesamt Nordrhein-Westfalen).

Klostermann, J. (1995): IV. Nordrhein-Westfalen. - In: Benda, L. (ed.): Das Quartär Deutschlands: 59-94; Berlin (Gebr. Bornträger)

KNELLER, B.C. \& BRANNEY, M.J. (1995): Sustained high-density turbidity currents and the deposition of thick massive sands. - Sedimentology, 42: 607-616.

Koenen, A. v. \& Müller, G. (1900): Erläuterungen zu Blatt 4025 GrossFreden, Geologische Specialkarte von Preussen und den Thüringischen Staaten 1: 25000. - 28S.; Berlin.

KокEN, E. (1901): Beiträge zur Kenntnis des schwäbischen Diluviums. Neues Jahrbuch für Mineralogie, Geologie und Paläontologie, Beilagen-Band, 14: 120-170.

Könemann, P. (1995): Der Sand- und Kiesabbau im Wesertal an der Porta Westfalica - Ökonomische und ökologische Untersuchungen zur Belastung und Inwertsetzung des Naturraumpotentials. - Hannoversche Geographische Arbeiten, 50: 1-216.

KulLE, S. (1985): Drenthe-stadiale Staubecken-Sedimente (Pleistozän) und ihr Lagerungsverband aus zwei Aufschlüssen im Wesertal zwischen Rinteln und Hameln. - 58 S.; unpublished diploma thesis; University of Hannover.

Lambeck, K., Purcell, A., Funder, S., Kjaer, K.H., Larsen, E. \& Möller, P. (2006): Constraints on the Late Saalian to early Middle Weichselian ice sheet of Eurasia from the field data and rebound modelling. - Boreas, 35: 539-575.
LARoque, A., Dubois, J.-M.M. \& Leblon, B. (2003): A methology to reconstruct small and short-lived ice-dammed lakes in the Appalachians of Southern Québec. - Quaternary International, 99-100: 59-71.

LATZKe, A. (1996): Sedimente und Internbau des Kiessandkörpers von Freden/Leine. - 76 S.; unpublished diploma thesis; University of Hannover

LiEDTKe, H. (1981): Die nordische Vereisung in Mitteleuropa. - Forschung zur deutschen Landeskunde, 204: 1-307.

LiszKowsKI, J. (1993): The effects of Pleistocene ice-sheet loading/deloading cycles on the bedrock structure of Poland. - Folia Quaternaria, 64: 7-23.

Litt, T., Behre, K.-E., Meyer, K.-D., Stephan, H.-J. \& Wansa, S. (2007): Stratigraphische Begriffe für das Quartär des nordeutschen Vereisungsgebietes. - Eiszeitalter und Gegenwart, 56: 7-65.

LøNNE, I. (1995): Sedimentary facies and depositional architecture of icecontact glaciomarine systems. - Sedimentary Geology, 98: 13-43.

LøNNE, I. (2001): Dynamics of marine glacier termini read from moraine architecture. - Geology, 29: 199-202.

LüTtIG. G. (1954): Alt- und mittel-pleistozäne Eisrandlagen zwischen Harz und Weser. - Geologisches Jahrbuch, 70: 43-125.

LÜтTIG. G. (1958): Heisterbergphase und Vollgliederung des Drenthe-Stadiums. - Geologisches Jahrbuch, 75: 419-430.

LüTTIG. G. (1960): Neue Ergebnisse quartärgeschichtlicher Forschung im Raum Alfeld-Hameln-Elze. Geologisches Jahrbuch, 77: 337-390.

LüTTIG. G. (1962): Das Braunkohlebecken von Bornhausen am Harz. - Geologisches Jahrbuch, 79: 565-662.

Meinsen, J., Winsemann, J., Weitkamp, A., Landmeyer, N., Lenz, A. \& DöLLING, M. (in press): Middle Pleistocene (Saalian) lake outburst floods in the Münsterland Embayment (NW Germany): impacts and magnitudes. - Quaternary Science Reviews.

MERKт, J. (1978): Zur Bildung der Quellmoore bei Todenmann/Wesergebirge: Die geologischen Voraussetzungen. Geologisches Gutachten über die Ursachen der Bildung von Quellmooren bei Todenmann/Wesergebirge. - Arbeitsstudie für theoretische und angewandte Pflanzensoziologie, $1-3$

MeYER, T. (2003): Faziesarchitektur glazilakustriner Eiskontakt-Fächer in Südniedersachsen. - 230 S.; unpublished diploma thesis; University of Hannover.

MiotKe, F.-D. (1971): Die Landschaft an der Porta Westfalica. Teil 1: Die Naturlandschaft. - Jahrbuch der Geographischen Gesellschaft Hannover 1969: 1-256.

Moretti, I., Calassou, S., Victor, P., Molinaro, M. \& Maerten, L. (2003): Syn-sedimentary shear zones. - Petroleum Geoscience, 9: 221-232.

Mulder, T. \& Alexander, J. (2001): The physical character of subaqueous sedimentary density flows and their deposits. - Sedimentology, 48: 269-299.

MülLER, G. (1896): Glaziale Ablagerungen im südlichen Hannover und am nördlichen Harzrande. - Zeitschrift der deutschen Geologischen Gesellschaft, 48: 431-434

Naumann, E. (1922): Erläuterungen zu Blatt 3820 Rinteln, Geologische Karte von Preußen 1: 25 000. - 46 S.; Berlin.

NAumanN, E. (1927): Erläuterungen zu Blatt 3823 Eldagsen, Geologische Karte von Preußen 1: 25 000. - 57 S.; Berlin.

Naumann, E. \& BurRe O. (1927): Erläuterungen zu Blatt 3822 Hameln, Geologische Karte von Preußen 1: 25 000 - 77 S.; Berlin.

Nemec, W. (1990): Aspects of sediment movement on steep delta slopes. - In: Colella, A. \& Prior, B.D. (eds.): Coarse-Grained Deltas. - IAS Specical Publications, 10: 29-73.

NemeC, W., LønNe, I. \& BlikRA, L.H. (1999): The Kregnes moraine in Gaudalen, west-central Norway: Anatomy of a Younger Dryas proglacial delta in a paleofjord basin. - Boreas, 28: 454-476.

Passchier, S., Laban, C., Mesdag, C.S. \& Rijsdijk, K.F. (2010): Subglacial bed conditions during Late Pleistocene glacitaions and their impact on ice dynamics in the southern North Sea. - Boreas, 39: 633-647.

Petter, A.L. \& Muto, T. (2008): Sustained alluvial aggradation and autogenic detachment of the alluvial river from the shoreline in response to steady fall of relative sea-level. - Journal of Sedimentary Research, 78: 98-111.

PLink-BJörkLund, P. \& RonNerT, L. (1999): Depositional processes and internal architecture of late Weichselian ice-margin submarine fan and delta settings, Swedish west coast. - Sedimentology, 46: 215-234.

Posamentier, H.W. Allan, G.P. \& James, D.P. (1992): High-resolution sequence stratigraphy - the east Coulee delta, Alberta. - Journal of Sedimentary Petrology, 62: 310-317. 
Postma, G. \& Cruickshank, C. (1988): Sedimentology of a late Weichselian to Holocene terraced fan delta, Varangerfjord, northern Norway. - In: Nemec, W. \& Steel, R.J. (eds.): Fan Deltas: Sedimentology and Tectonic Settings: 144-157; London (Blackie).

Powell, R.D. (1990): Glacimarine processes at grounding-line fans and their growth to ice-contact deltas. - In: Dowdeswell, J.A. \& Scourse, J.D (eds.): Glacimarine Environments: Processes and Sediments. - Geological Society of London Special Publications, 53: 53-73.

Powell, R.D. \& Domack (1995): Modern Glaciomarine Environments. - In: MenZIES, J. (ed.): Modern Glacial Environments: 445 -486; Oxford (Butterworth -Heinemann).

Prange, W. (1995): Kleintektonische Untersuchungen in Lockersedimenten. - Schriften des Naturwissenschaftlichen Vereins Schleswig-Holsteins, 65: 47-65.

Rakowski, B. (1990): Aufbau und Genese der „Emme“ - eines Schmelzwasser-Schwemmfächers an der Südseite des Wesergebirges bei Kleinenbremen (Bückeburg). - 95 S.; unpublished diploma thesis; University of Hannover.

Rausch, M. (1975): Der „Dropstein-Laminit“ von Bögerhof und seine Zuordnung zu den Drenthe-zeitlichen Ablagerungen des Wesertals bei Rinteln. - Mitteilungen aus dem Geologischen Institut der Universität Hannover, 12: 51-84.

Rausch, M. (1977): Fluß-, Schmelzwasser- und Solifluktionsablagerungen im Terrassengebiet der Leine und der Innerste. - Mitteilungen aus dem Geologischen Institut der Universität Hannover, 14: 1-82.

Reicherter, K., Kaiser, A. \& Stackebrandt, W. (2005): The post-glacial landscape evolution of the North German Basin: morphology, neotectonics and crustal deformation. - International Journal of Earth Sciences, 94: 1083-1093.

Ritchie, B.D., Gawthorpe, R.L. \& Hardy, S. (2004a): Three-dimensional numerical modelling of deltaic depositional sequences 1: influence of the rate and magnitude of sea-level change. - Journal of Sedimentary Research, 74: 203-220.

Ritchie, B.D., Gawthorpe, R.L. \& HaRdy, S. (2004b): Three-dimensional numerical modelling of deltaic depositional sequences 2: influence of local controls. - Journal of Sedimentary Research, 74: 221-238.

Rohde, P. \& Thiem, W. (1998): Die eiszeitliche Weser im heutigen Weserund Leinetal. - In: Feldmann, L. \& MEYER, K.D. (eds.): Quartär in Niedersachsen. Exkursionsführer zur Jubiläums-Hauptversammlung der Deutschen Quartärvereinigung in Hannover, Exkursion C: 89-153.

RöHм, H. (1985): Bau und Zusammensetzung Saale-Eiszeitlicher Sedimentkörper im Raum Hausberge-Veltheim/Weser. - 107 S.; unpublished diploma thesis; University of Hannover.

Russell, H.A.J. \& ARnotT, R.W.C. (2003): Hydraulic-jump and hyperconcentrated-flow deposits of a glacigenic subaqueous fan: Oak Ridge Moraine, southern Ontario, Canada. - Journal of Sedimentary Research, 73: 887-905.

Russell, H.A.J., Sharpe, D.R. \& BAJC, A.F. (2007): Sedimentary signatures of the Waterloo Moraine, Ontario, Canada. - In: Hambrey, M., Christoffersen, P., Glasser N \& Hubbard, B. (eds.): Glacial Processes and Products. - IAS Specical Publications, 39: 85-108.

Schumm, S.A. (1993): River response to base level change: implications for sequence stratigrahy. - Journal of Geology, 101: 279-294.

Schwarzbach, M. (1950): Kamebildungen im Leinetal (Hannover). - Neues Jahrbuch für Geologie und Paläontologie Monatshefte: 328-329.

SELSING, L. (1981): Stress analysis on conjugate normal faults in unconsolidated Weichselian glacial sediments from Brorfelde, Denmark. Boreas, 10: 275-279.

Seraphim, E. T. (1973): Eine saalezeitliche Mittelmoräne zwischen Teutoburger Wald und Wiehengebirge. - Eiszeitalter und Gegenwart, 23/24: 116-129.

Seraphim, E. T. (1972): Wege und Halte des saalezeitlichen Inlandeises zwischen Osning und Weser. - Geologisches Jahrbuch, Reihe A, 3 $1-85$.

Sharpe, D. R. (1988): Glaciomarine fan deposits in the Champlain Sea. In: GADD, N.R. (ed.): The Late Quaternary Development of the Champlain Sea Basin. - Canadian Geological Association Special Paper, 35: 63-82.

SHARpe, D. R. \& CowAN, W.R. (1990): Moraine formation in northwester Ontario: product of subglacial fluvial and glacilacustrine sedimentation. - Canadian Journal of Earth Sciences, 27: 1478-1486.

SiEgERT, L. (1912) Über die Entwicklung des Wesertales. - Zeitschrift der deutschen Geologischen Gesellschaft, 64: 233-264.

Siegert, L. (1921): Beiträge zur Kenntnis des Pliozäns und der diluvialen Terrassen im Flußgebiet der Weser. - Abhandlungen der Preußischen geologischen Landes-Anstalt, Neue Folge, 90:1-130.
Sirocko, F., Szeder, T., Seelos, C., Lehné, R., Rein, B., Schneider, W.M. \& Dimke, M. (2002): Young tectonic and halokinetic movements in the North-German-Basin: its effect on formation of modern rivers and subsurface morphology. - Netherlands Journal of Geosciences / Geologie en Mijnbouw, 81: 431-441.

Sirocko, F., Reicherter, K., Lehné, R., Hübscher, C., Winsemann, J. \& STACKEBRANDT, W. (2008): Glaciation, salt and the present landscape. In: Littke, R., Bayer, U., Gajewski, D. \& Nelskamp, S. (eds): Dynamics of Complex Intracontinental Basins - The Central European Basin System: 232-245, Berlin (Springer)

Skupin, K., Speetzen, E. \& Zandstra, J.G. (1993): Die Eiszeit in Nordwestdeutschland. Zur Vereisung der Westfälischen Bucht und angrenzender Gebiete. - 95 S.; Krefeld (Geologisches Landesamt Nordrhein-Westfalen)

Skupin, K., Speetzen, E. \& Zandstra, J. G. (2003): Die Eiszeit in NordostWestfalen und angrenzenden Gebieten Niedersachsens. - 96 S.; Krefeld (Geologischer Dienst Nordrhein-Westfalen).

Soergel, W. (1921): Die Ursachen der diluvialen Aufschotterung und Erosion. - Zeitschrift der deutschen Geologischen Gesellschaft, 64: 233-264.

SoHN, Y.K. (2000): Depositional processes of submarine debris flows in the Miocene fan deltas, Pohang basin, SE Korea with special reference to flow transformation. - Journal of Sedimentary Research, 70: 491-503.

Sohn, Y.K., Kim, S.B., Hwang, I.G., BAнк, J.J., Сноe, M.Y., \& С $\mathrm{CHOugh}$ S.K. (1997): Characteristics and depositional processes of large-scale gravelly Gilbert-type foresets in the Miocene Dousan fan delta, Pohang Basin, SE Korea. - Journal of Sedimentary Research, 67: 30-141.

Sohn, Y.K., Choz, M.Y. \& Jo, H.R. (2002): Transition from debris flow to hyperconcentrated flow in a submarine channel (the Cretaceous Cerro Toro Formation, southern Chile). - Terra Nova 14: 405-415.

SpethmanN, H. (1908): Glaziale Stillstandslagen im Gebiet der mittleren Weser. - Mitteilungen der Geographischen Gesellschaft Lübeck, 22: $1-17$.

STACH, E. (1930): Die Eisrandbildungen an der Porta Westfalica. - Jahrbuch der Preussischen Geologischen Landes-Anstalt, 51: 174-187.

Stewart, I.S., Sauber, J. \& Rose, J. (2000): Glacio-seismotectonics: ice sheets, crustal deformation and seismicity. - Quaternary Science Reviews, 19: 1367-1389.

StOKEs, C.R. \& CLARK, C.D. (2004): Evolution of late glacial ice-marginal lakes on the northwestern Canadian Shield and their influence on the location of the Dubawnt Lake palaeo-ice stream. - Palaeogeography, Palaeoclimatology, Palaeoecology, 215: 155-171.

Struck, R. (1904): Der baltische Höhenrücken in Holstein. - Mitteilungen der Geographischen Gesellschaft und naturkundliches Museum Lübeck, 19: 1-103.

Teller, J.T. (1995): History and drainage of large ice-dammed lakes along the Laurentide Ice Sheet. - Ouaternary International, 28: 83-92.

Thiem, W. (1972): Geomorphologie des westlichen Harzrandes und seiner Fußregion. - Jahrbuch der Geographischen Gesellschaft Hannover, Sonderheft 6: 1-271.

Thiem, W. (1988): Das Oberwesertal im Raum Polle-Bodenwerder-Hehlen. $\mathrm{Zu}$ aktuellen Problemen der Talgeschichte der Oberweser im Quartär. - Jahrbuch der Geographischen Gesellschaft Hannover, 14: 273-326.

Tномаs, R.H. (1979): Ice shelves: a review. - Journal of Glaciology, 24: 273-286.

Tноме, K.N. (1983): Gletschererosion und -akkumulation im Münsterland und angrenzenden Gebieten. - Neues Jahrbuch für Geologie und Paläontologie, Abhandlungen, 166: 116-138.

Tноме, K.N. (1998): Einführung in das Quartär: das Zeitalter der Gletscher. - 309 S. Berlin (Springer).

Uebersohn, D. (1990): Aufbau und Alter pleistozäner Lockersedimente bei Bornhausen (nordwestliches Harzvorland). - 57 S.; unpublished diploma thesis; University of Hannover.

VAN DEN Berg, M.W. \& BeEts, D.J. (1987): Saalian glacial deposits and morphology in The Netherlands. - In: VAN DER MEER, J.J.M. (ed): Tills and Glaciotectonics, 235-251; Rotterdam (Balkema)

Vollbrecht, A. \& TANner, D.C. (in press): Der Leinetalgraben als Teil einer regionalen Pull-Apart-Struktur. - In: Leiss, B., TANner, D. \& Vollbrecht, A. (eds.): Neuere Untersuchungen zur Geologie der Leinetalgrabenstruktur - Bausteine zur Erkundung des geothermischen Nutzungspotentials in der Region Göttingen. - Universitätsdruck Göttingen.

WALDECK, H. (1975): Erläuterungen zu Blatt 4023 Eschershausen, Geologische Karte von Niedersachsen 1: 25 000. - 189 S.; Hannover.

Wahle, M., Brandes, C, Polom, U. \& Winsemann, J. (2010): Evolution of Middle Pleistocene glacial Lake Leine (NW Germany): challenges on 
the way to reconstruct lake-level history and palaeogeography. - Abstract volume, S. 173; Deuqua Meeting 2010, Greifswald.

Warren, C.R., Greene, D.R. \& Glasser, N.F. (1995): Glaciar Upsala, Patagonia: Rapid calving retreat in fresh water. - Annals of Glaciology, 21: 311-316.

Wellmann, P. (1998): Kies-/Sandkörper im Wesertal zwischen Rinteln und Porta Westfalica. - Mitteilungen aus dem Geologischen Institut der Universität Hannover, 38: 203-212.

Wermbter, H. (1891): Der Gebirgsbau des Leinetals zwischen Greene und Banteln. - Neues Jahrbuch für Mineralogie, Geologie und Paläontologie, Beilagen-Band, 7: 386-398.

Winsborrow, M.C.M., Clarke, C.D. \& Stokes, C.R. (2010): What controls the location of ice streams? - Earth-Science Reviews, 103: 45-59

Winsemann, J., Asprion, U., Meyer, T., Schultz, H., \& Victor P. (2003): Evidence of iceberg ploughing in a subaqueous ice-contact fan, glacial Lake Rinteln, Northwest Germany. - Boreas, 32: 386-398.

Winsemann, J., Asprion, U. \& Meyer, T. (2004): Sequence analysis of early Saalian glacial lake deposits (NW Germany): evidence of rapid local ice margin retreat and related calving processes. - Sedimentary Geology, 165: 223-251.

Winsemann, J., Asprion, U. \& Meyer, T. (2007): Lake-level control on ice-margin subaqueous fans, glacial Lake Rinteln. - In: Hambrey, M.
Christoffersen, P., Glasser N \& Hubbard, B. (eds.): Glacial Processes and Products. - IAS Specical Publications, 39: 121-148.

Winsemann, J., Asprion, U., Meyer, T. \& Schramm, C. (2007): Facies characteristics of Middle Pleistocene (Saalian) ice-margin subaqueous fan and delta deposits, glacial Lake Leine, NW Germany. - Sedimentary Geology, 193: 105-129.

Winsemann, J., Hornung, J.J., Meinsen. J., Asprion, U., Meinsen, Polom, Brandes, C. Bussmann, M \& Weber, C. (2009): Anatomy of a subaqueous ice-contact fan and delta complex, Middle Pleistocene, NW Germany. - Sedimentology, 56: 1041-1076.

Winsemann, J., BRAndes, C. \& Polom, U. (2011): Response of a proglacial delta to rapid high-amplitude lake level change: an integration of outcrop data and high resolution shear wave seismic. - Basin Research, 23: 22-52. Doi: 10.1111/j.1365 -2117.2010.00468.x.

Wortmann, H. (1968): Die morphogenetische Gliederung der Quartärbasis des Wiehengebirgsvorlandes in Nordwestdeutschland. - Eiszeitalter und Gegenwart 19: 227-239.

Wortmann, H., Wortmann, A. (1987): Glaziäre Ablagerungen und Terrassengliederung der Weser im Raum zwischen Eisbergen und Porta Westfalica (Nordwestdeutschland). - Eiszeitalter und Gegenwart 37: 93-98. 